\title{
Altered Steroidome in Women with Gestational Diabetes Mellitus: Focus on Neuroactive and Immunomodulatory Steroids from the 24th Week of Pregnancy to Labor
}

\author{
Leona Ondřejíková ${ }^{1}$, Antonín Pařízek ${ }^{2}$, Patrik Šimják ${ }^{2}$, Daniela Vejražková ${ }^{1}$, Marta Velíková ${ }^{1}$, \\ Kateřina Anderlová ${ }^{2}$, Michala Vosátková ${ }^{1}$, Hana Krejčí ${ }^{2}$, Michal Koucký ${ }^{2}$, Radmila Kancheva ${ }^{1}$, \\ Michaela Dušková ${ }^{1}$, Markéta Vaňková ${ }^{1}{ }^{\mathbb{D}}{ }$, Josef Bulant $^{1}$ and Martin Hill ${ }^{1, *}$ \\ 1 Institute of Endocrinology, 11694 Prague, Czech Republic; londrejikova@endo.cz (L.O.); \\ dvejrazkova@endo.cz (D.V.); mvelikova@endo.cz (M.V.); mvosatkova@endo.cz (M.V.); \\ rkanceva@endo.cz (R.K.); mduskova@endo.cz (M.D.); mvankova@endo.cz (M.V.); jbulant@endo.cz (J.B.) \\ 2 Department of Gynecology and Obstetrics, First Faculty of Medicine, General University Hospital in Prague, \\ Charles University in Prague, 12808 Prague, Czech Republic; antonin.parizek@lf1.cuni.cz (A.P.); \\ Patrik.simjak@lf1.cuni.cz (P.Š.); katerina.anderlova@lf1.cuni.cz (K.A.); hana.krejci@lf1.cuni.cz (H.K.); \\ michal.koucky@lf1.cuni.cz (M.K.) \\ * Correspondence: mhill@endo.cz; Tel.: +420-224-905-246
}

check for updates

Citation: Ondřejíková, L.; Pařízek,

A.; Šimják, P.; Vejražková, D.;

Velíková, M.; Anderlová, K.;

Vosátková, M.; Krejčí, H.; Koucký, M.;

Kancheva, R.; et al. Altered

Steroidome in Women with

Gestational Diabetes Mellitus: Focus

on Neuroactive and Immunomodulatory Steroids from the 24th Week of Pregnancy to Labor. Biomolecules 2021, 11, 1746. https://doi.org/10.3390/ biom11121746

Academic Editor: Vladimir N. Uversky

Received: 28 September 2021 Accepted: 20 November 2021 Published: 23 November 2021

Publisher's Note: MDPI stays neutral with regard to jurisdictional claims in published maps and institutional affiliations.

Copyright: (c) 2021 by the authors. Licensee MDPI, Basel, Switzerland. This article is an open access article distributed under the terms and conditions of the Creative Commons Attribution (CC BY) license (https:/ / creativecommons.org/licenses/by/ $4.0 /)$.

\begin{abstract}
Gestational diabetes mellitus (GDM) is a complication in pregnancy, but studies focused on the steroidome in patients with GDM are not available in the public domain. This article evaluates the steroidome in GDM+ and GDM - women and its changes from 24 weeks ( \pm of gestation) to labor. The study included GDM+ $(n=44)$ and GDM - women $(n=33)$, in weeks $24-28,30-36$ of gestation and at labor and mixed umbilical blood after delivery. Steroidomic data (101 steroids quantified by GC-MS/MS) support the concept that the increasing diabetogenic effects with the approaching term are associated with mounting progesterone levels. The GDM+ group showed lower levels of testosterone (due to reduced AKR1C3 activity), estradiol (due to a shift from the HSD17B1 towards HSD17B2 activity), 7-oxygenated androgens (competing with cortisone for HSD11B1 and shifting the balance from diabetogenic cortisol towards the inactive cortisone), reduced activities of SRD5As, and CYP17A1 in the hydroxylase but higher CYP17A1 activity in the lyase step. With the approaching term, the authors found rising activities of CYP3A7, AKR1C1, CYP17A1 in its hydroxylase step, but a decline in its lyase step, rising conjugation of neuroinhibitory and pregnancy-stabilizing steroids and weakening AKR1D1 activity.
\end{abstract}

Keywords: gestational diabetes mellitus; steroidome; neuroactive steroids; immunoprotective steroids; gestational age; maternal blood; mixed cord blood; gas chromatography-tandem mass spectrometry

\section{Introduction}

Gestational diabetes mellitus (GDM) is a serious pregnancy complication, in which women without previously diagnosed type 2 diabetes (DM2) develop persistent hyperglycemia during pregnancy. Hyperglycemia during pregnancy is generally induced by glucose intolerance due to the dysfunction of pancreatic $\beta$-cells in context with chronic insulin resistance (IR). Advanced maternal age, obesity, and a family history of diabetes are common risk factors of GDM. GDM is regularly associated with macrosomia, birth complications of the infant, increased risk of maternal cardiovascular disease, and predisposition to DM2 in both mother and child [1]. The prevalence of GDM is about $15-20 \%$ of pregnancies worldwide, with an increasing trend mostly linked to accelerating obesity [1]. A number of interrelated factors (including steroids) affecting both insulin secretion (IS) and IR are involved in GDM pathophysiology [1]. 
The normal pregnancy is accompanied by higher IR, reduced hepatic insulin extraction and glucose effectiveness, higher levels of leptin, lower adiponectin concentrations, increased lipolysis and higher levels of triglycerides [2,3]. The pregnancy complicated with GDM is additionally associated with increased levels of inflammatory cytokines, higher macrophage infiltration and increased lipolysis. In contrast to healthy pregnancy with mild IR, the pregnancy complicated with GDM exhibits severe IR, hyperglycemia, leptin resistance, hyperlipidemia and oxidative stress. Women with GDM are unable to compensate for the IR of pregnancy by intensified IS [4].

In late gestation, the maternal system switches from the anabolic to the catabolic phase. Despite this transformation, maternal blood glucose remains constant or even slightly declines with advancing gestation, primarily due to the increased IS [4]. However, in mothers with GDM, the $\beta$-cells may deteriorate due to excessive insulin production persistently exhausting the cells. Furthermore, GDM is also associated with upregulated gluconeogenesis in the liver. While in normal pregnancy the maternal insulin sensitivity returns to pre-pregnancy levels shortly after labor, in GDM patients the disbalance frequently persists in the postpartum period and may develop to overt DM2 [1].

PregS and DHEAS stimulate IS through positive modulation of non-selective type 3 melastatin ion channels (TRPM3) [5,6]. Furthermore, PregS activates signal cascades involved in the amplified expression of activator protein 1 (AP-1) in the $\beta$-cells. In addition to TRPM3, L-type $\mathrm{Ca}^{2+}$ channels are also involved in $\beta$-cell activation [7]. PregS may also be involved in IS through positive modulation type 1 melastatin ion channels (TRPM1) [8]. Besides PregS and another abundant steroid, conjugate isopregnanolone sulfate reaches micromolar concentrations during pregnancy and inhibits specific proton-activated outwardly rectifying anion channels (PAORAC), which may further contribute to the increased $\beta$-cell activity [9].

However, the effects of PregS on IS do not appear to be unidirectional. PregS inhibits nicotine-acetylcholine receptors (nAChR) and restrains the influx of $\mathrm{Ca}^{2+}$ and $\mathrm{Na}^{+}$ions into $\beta$-cells, thereby suppressing IS [10] and DHEAS regardless of pregnancy status, has a similar effect [11].

An increased activity of $\beta$-cells in the third trimester of gestation is linked to an increase in progesterone levels. It is an adaptive response to the increasing energy requirements of a fetus requiring increasing glucose and lipid intake. Progesterone is known as a diabetogenic steroid that acts through suppression of glucose transporter type 4 expression (GLUT-4) [12]. Unlike prolactin and hPL, which stimulate IS, progesterone suppresses their effects by down-regulation of $\beta$-cell function in the later stages of gestation [12]. Also, nuclear progesterone receptors may be involved in GDM pathophysiology [13]. These receptors are expressed in the pancreas, predominantly in glucagon-producing cells [14]. Unlike sulfated $\Delta^{5}$ steroids, progesterone inhibits the permeability of TRPM3 channels at levels typical for the luteal menstrual phase [15].

Alternatively, progesterone at concentrations common for the luteal menstrual phase and DHEA activate purinergic ionotropic $\mathrm{P} 2 \mathrm{X}$ receptors [16]. The subtypes of $\mathrm{P} 2 \mathrm{X}$ receptors are expressed in different tissues, including $\beta$-cells, and facilitate the influx of $\mathrm{Ca}^{2+}$ and $\mathrm{Na}^{+}$ ions at low glucose concentrations, followed by the depolarization of the cell membrane and IS [17].

While PregS and allopregnanolone inhibit the activity of AMPA/kainate receptors [18,19] and hence glucagon secretion, estradiol may function as their antagonist [20]. The $\beta$-cells produce significant amounts of $\gamma$-aminobutyric acid (GABA), which activates type A GABA receptors $\left(\mathrm{GABA}_{\mathrm{A}} \mathrm{R}\right)$ and subsequently inhibits glucagon secretion in pancreatic $\alpha$-cells [21]. At low concentrations, GABA increases IS, but inhibits it at higher concentrations [22]. GABAergic progesterone metabolites, such as allopregnanolone and pregnanolone in concentrations common for fetal and maternal circulation, increase $G_{A B A} R$ permeability for chloride ions [23,24], while sulfated $\Delta^{5}$ steroids are their antagonists $[23,25]$. The effect of listed GABAergic steroids on IS can therefore be considered as well. 
Estradiol levels in the maternal circulation exceed by roughly two orders of magnitude the values common in the luteal phase of the menstrual cycle [26]. Estrogens promote energy consumption and food intake at the central level, increase glucose uptake in muscles and adipocytes, and reduce liver gluconeogenesis [27]. Estradiol binds to estrogen receptors (ER), thus modulating the transcription of target pancreatic genes [12]. Type $\alpha$ ER (ER $\alpha)$ are included in IS and nutrient homeostasis and type $\beta$ ER (ER $\beta)$ augments IS. Furthermore, G protein-coupled ER (GPER), is also involved in IS [27]. ER $\alpha$, which are expressed in pancreatic islets [28], stimulate glucose transporter 4 (GLUT4) expression, which is a limiting step in insulin-induced glucose uptake in skeletal muscles [12]. In addition, ER $\alpha$ may also operate at the central level, as disruption of $\operatorname{ER} \alpha$ leads to increased visceral adiposity, hyperphagia, hyperglycemia, and impaired energy exposure [29].

In pancreatic $\beta$-cells, estradiol increases cyclic guanosine monophosphate levels and protein kinase $G$ activity, which subsequently reduces $K_{\text {ATP }}$ activity through the rapid and reversible closure of $\mathrm{K}_{\mathrm{ATP}}$ channels. In synergy with increased glucose levels, estradiol depolarizes the cell membrane, triggering electrical activity and $\mathrm{Ca}^{2+}$ influx into the cell via activation of L-type $\mathrm{Ca}^{2+}$ channels. In addition, estradiol inhibits the permeability of voltage dependent potassium channels, which also activates the $\beta$-cells [12,30]. It should be mentioned that the lack of estradiol leads to a decrease of ATP-sensitive potassium channels $\left(\mathrm{K}_{\mathrm{ATP}}\right)$ gene expression and a consequent decrease in IS [12].

Low glucose levels induce increased permeability of AMPA/kainate receptors for $\mathrm{Ca}^{2+}$ ions and the opening of voltage dependent $\mathrm{Ca}^{2+}$ channels, which stimulates glucagon secretion [31]. In glucagon synthesizing $\alpha$-cells, estradiol suppresses $\mathrm{Ca}^{2+}$ oscillations generated by low glucose levels and thus reduces glucagon secretion. [32]. Lastly, the estrogens increase the CNS and serum levels of GABAergic allopregnanolone [33].

Data from the literature indicate that the effect of steroids on glucose homeostasis is complex, and their resulting effect is likely to be contingent upon a variety of incremental effects that may be mutually antagonistic. Furthermore, while a short-term increase in the levels of some steroids may promote the IS, the long-term hyperstimulation of the $\beta$-cells during pregnancy may result in impaired IS due to exhaustion of the $\beta$-cells, which could be related to GDM pathophysiology [34]. In addition, it is also common in neuroactive steroids for the same substances to be neuro-excitatory on some receptors affecting glucose homeostasis, while acting as neuro-inhibitors on others. There is also a significant amount of data explaining the association between cortisol synthesis and its metabolism on one hand and disturbed glucose homeostasis on the other [35], yet less information is available about the anti-glucocorticoid and anti-inflammatory effects of 7-oxygenated androstanes in this respect [36,37], and particularly if related to the pathophysiology of GDM [38].

Although current evidence indicates a significant role for steroids in the development of GDM and in spite of the fact that steroid levels in pregnancy usually reach values 1-3 orders of magnitude higher compared to the situation in non-pregnant subjects, the mechanism of the influence of individual risk factors on the onset and course of GDM is not yet fully understood. The data regarding the role of steroids in the pathophysiology of GDM is deficient, and a study focused on alterations of the steroidome in women with GDM is lacking. The aim of this study was to evaluate the alterations in the maternal and fetal steroidome in GDM+ women and GDM- women from week 24 of pregnancy to birth and their relations to the physiology of pregnancy and parturition and to the pathophysiology of GDM.

\section{Materials and Methods}

\subsection{Subjects, Sample Collection, Serum Preparation, and Storage}

The study population consisted of two groups. The GDM+ group included pregnant women diagnosed with gestational diabetes via a $75 \mathrm{~g}$, 2-h oral glucose tolerance test using IADPSG criteria ( $n=44,21$ female newborns, 23 male newborns). The GDM-group involved controls without GDM ( $n=33,21$ female newborns, 12 male newborns). The following three samples were collected from all participants: week 24-28 of gestation 
(collection of blood from maternal cubital vein), week 30-36 of gestation (collection of blood from maternal cubital vein), labor (collection of blood from maternal cubital vein before delivery). The fourth sample was collected from the mixed umbilical cord blood after delivery. Serum was obtained from blood sample after centrifugation for $5 \mathrm{~min}$ at $2000 \times g$ at $0{ }^{\circ} \mathrm{C}$ and stored at $-20^{\circ} \mathrm{C}$ until analyzed.

The study was conducted according to the Declaration of Helsinki, the International Conference of Harmonization (ICH) principles of Good Clinical Practice (GCP), and approved by the Ethics Committee of the Institute of Endocrinology (16 May 2016). After obtaining Ethics Committee approval, written informed consent was obtained from all patients. They were given sufficient time to discuss the study with their physician, to raise questions and to decide whether to participate or not. After fulfilling the inclusion study criteria, the participants were enrolled in the study.

\subsection{Analytical Method}

In total, 101 analytes were quantified in the blood from the cubital vein and in mixed umbilical cord blood of women with GDM and in corresponding controls. The steroids were measured using our previously published GC-MS/MS method [39]. The analytes, which were significantly related to GDM, are shown in Table 1, while those unrelated to GDM are displayed in Table S1.

Table 1. Profiles of steroids from week 24 of gestation to labor, which were significantly related to GDM.

\begin{tabular}{|c|c|c|c|c|}
\hline \multirow{2}{*}{ Steroid } & \multirow{2}{*}{ GDM } & \multicolumn{3}{|c|}{ GDM $\times$ Stage } \\
\hline & & Week $24-28$ of Gestation (a) & Week $30-36$ of Gestation (b) & Labor (c) \\
\hline \multirow{3}{*}{ Pregnenolone [nM] } & - & $4.7(4.3,5.2)$ & $5.2(4.8,5.7)$ & $3.8(3.4,4.2)$ \\
\hline & + & $6(5.5,6.5) *$ & $6.3(5.8,6.8) *$ & $5.2(4.7,5.6) *$ \\
\hline & & \multicolumn{3}{|c|}{$\mathrm{G}(\mathrm{WP}): \mathrm{F}=21.8, p<0.001 ; \mathrm{S}: \mathrm{F}=8.9, p<0.001 ; \mathrm{G} \times \mathrm{S}: \mathrm{F}=0.4, p=0.7 ; \mathrm{GDM}-\mathrm{c}<\mathrm{a}, \mathrm{c}<\mathrm{b} ; \mathrm{GDM}+\mathrm{c}<\mathrm{b}$} \\
\hline \multirow{3}{*}{$\begin{array}{c}16 \alpha- \\
\text { Hydroxypregnenolone } \\
\text { sulfate }[\mathrm{nM}]\end{array}$} & - & $39(30,52)$ & $68(52,91)$ & $110(83,150)$ \\
\hline & + & $26(20,34)$ & $50(38,65)$ & $89(67,120)$ \\
\hline & & \multicolumn{3}{|c|}{$\mathrm{G}(\mathrm{UP}): \mathrm{F}=4.2, p=0.044 ; \mathrm{S}: \mathrm{F}=18.2, p<0.001 ; \mathrm{G} \times \mathrm{S}: \mathrm{F}=0.2, p=0.851 ; \mathrm{GDM}-\mathrm{c}>\mathrm{a} ; \mathrm{GDM}+\mathrm{b}>\mathrm{a}, \mathrm{c}>\mathrm{a}, \mathrm{c}>\mathrm{b}$} \\
\hline \multirow{3}{*}{$\begin{array}{c}20 \alpha- \\
\text { Dihydropregnenolone } \\
\text { sulfate }[\mathrm{nM}]\end{array}$} & - & $280(270,300)$ & $280(260,290)$ & $410(380,440)$ \\
\hline & + & $320(300,340)$ & $320(300,340) *$ & $470(440,500)$ \\
\hline & & \multicolumn{3}{|c|}{$\mathrm{G}(\mathrm{UP}): \mathrm{F}=11.8, p<0.001 ; \mathrm{S}: \mathrm{F}=51.5, p<0.001 ; \mathrm{G} \times \mathrm{S}: \mathrm{F}=0.1, p=0.892 ; \mathrm{GDM}-\mathrm{c}>\mathrm{a}, \mathrm{c}>\mathrm{b} ; \mathrm{GDM}+\mathrm{c}>\mathrm{a}, \mathrm{c}>\mathrm{b}$} \\
\hline \multirow{3}{*}{ DHEA sulfate $[\mu \mathrm{M}]$} & - & $1.3(1.2,1.4)$ & $1.2(1.1,1.3)$ & $1.6(1.5,1.8)$ \\
\hline & + & $1.5(1.4,1.6)$ & $1.3(1.2,1.4)$ & $1.8(1.7,1.9)$ \\
\hline & & \multicolumn{3}{|c|}{$\mathrm{G}(\mathrm{UP}): \mathrm{F}=4.7, p=0.032 ; \mathrm{S}: \mathrm{F}=21.8, p<0.001 ; \mathrm{G} \times \mathrm{S}: \mathrm{F}=0.1, p=0.865 ; \mathrm{GDM}-\mathrm{c}>\mathrm{a}, \mathrm{c}>\mathrm{b} ; \mathrm{GDM}+\mathrm{c}>\mathrm{a}, \mathrm{c}>\mathrm{b}$} \\
\hline \multirow{3}{*}{$7 \alpha$-Hydroxy-DHEA [nM] } & - & $0.31(0.26,0.37)$ & $0.38(0.32,0.45)$ & $0.87(0.75,1)$ \\
\hline & + & $0.22(0.18,0.26)$ & $0.29(0.24,0.34)$ & $0.72(0.61,0.84)$ \\
\hline & & \multicolumn{3}{|c|}{$\mathrm{G}(\mathrm{UP}): \mathrm{F}=7.7, p=0.006 ; \mathrm{S}: \mathrm{F}=53.8, p<0.001 ; \mathrm{G} \times \mathrm{S}: \mathrm{F}=0.2, p=0.862 ; \mathrm{GDM}-\mathrm{c}>\mathrm{a}, \mathrm{c}>\mathrm{b} ; \mathrm{GDM}+\mathrm{c}>\mathrm{a}, \mathrm{c}>\mathrm{b}$} \\
\hline \multirow{3}{*}{$7 \beta$-Hydroxy-DHEA [nM] } & - & $0.34(0.3,0.38)$ & $0.36(0.31,0.4)$ & $0.52(0.47,0.58)$ \\
\hline & + & $0.24(0.2,0.27)$ * & $0.29(0.25,0.33)$ & $0.41(0.36,0.46)$ * \\
\hline & & \multicolumn{3}{|c|}{$\mathrm{G}(\mathrm{WP}): \mathrm{F}=13.4, p<0.001 ; \mathrm{S}: \mathrm{F}=17.6, p<0.001 ; \mathrm{G} \times \mathrm{S}: \mathrm{F}=0.3, p=0.768 ; \mathrm{GDM}-\mathrm{c}>\mathrm{a}, \mathrm{c}>\mathrm{b} ; \mathrm{GDM}+\mathrm{c}>\mathrm{a}, \mathrm{c}>\mathrm{b}$} \\
\hline \multirow{3}{*}{$\begin{array}{l}\text { 5-Androstene- } 3 \beta, 7 \alpha, \\
\quad 17 \beta \text {-triol }[\mathrm{nM}]\end{array}$} & - & $0.13(0.11,0.15)$ & $0.14(0.12,0.16)$ & $0.34(0.3,0.39)$ \\
\hline & + & $0.11(0.095,0.12)$ & $0.13(0.12,0.15)$ & $0.23(0.2,0.26)$ * \\
\hline & & \multicolumn{3}{|c|}{$\mathrm{G}(\mathrm{UP}): \mathrm{F}=8, p=0.006 ; \mathrm{S}: \mathrm{F}=57.9, p<0.001 ; \mathrm{G} \times \mathrm{S}: \mathrm{F}=2.6, p=0.082 ; \mathrm{GDM}-\mathrm{c}>\mathrm{a}, \mathrm{c}>\mathrm{b} ; \mathrm{GDM}+\mathrm{c}>\mathrm{a}, \mathrm{c}>\mathrm{b}$} \\
\hline \multirow{3}{*}{$\begin{array}{l}\text { 5-Androstene-3 } \beta \\
16 \alpha, 17 \beta \text {-triol }[\mathrm{nM}]\end{array}$} & - & $0.63(0.56,0.7)$ & $0.9(0.81,1)$ & $1.7(1.5,1.8)$ \\
\hline & + & $0.52(0.46,0.58)$ & $0.89(0.8,1)$ & $1.2(1.1,1.3)$ * \\
\hline & & \multicolumn{3}{|c|}{$\begin{array}{c}\mathrm{G}(\mathrm{UP}): \mathrm{F}=8.8, p=0.004 ; \mathrm{S}: \mathrm{F}=74.8, p<0.001 ; \mathrm{G} \times \mathrm{S}: \mathrm{F}=2.9, p=0.059 ; \mathrm{GDM}-\mathrm{b}>\mathrm{a}, \mathrm{c}>\mathrm{a}, \mathrm{c}>\mathrm{b} ; \mathrm{GDM}+\mathrm{b}>\mathrm{a} \\
\mathrm{c}>\mathrm{a}, \mathrm{c}>\mathrm{b}\end{array}$} \\
\hline \multirow{3}{*}{$\begin{array}{l}\text { 5-Androstene-3 } \beta \\
16 \alpha, 17 \beta \text {-triol sulfate }[\mathrm{nM}]\end{array}$} & - & $93(83,100)$ & $140(130,160)$ & $260(240,290)$ \\
\hline & + & $78(70,86)$ & $120(110,130)$ & $230(200,250)$ \\
\hline & & \multicolumn{3}{|c|}{$\begin{array}{c}\mathrm{G}(\mathrm{UP}): \mathrm{F}=7.7, p=0.007 ; \mathrm{S}: \mathrm{F}=116.8, p<0.001 ; \mathrm{G} \times \mathrm{S}: \mathrm{F}=0, p=0.989 ; \mathrm{GDM}-\mathrm{b}>\mathrm{a}, \mathrm{c}>\mathrm{a}, \mathrm{c}>\mathrm{b} ; \mathrm{GDM}+\mathrm{b}>\mathrm{a}, \\
\mathrm{c}>\mathrm{a}, \mathrm{c}>\mathrm{b}\end{array}$} \\
\hline \multirow{3}{*}{ Progesterone [nM] } & - & $280(250,310)$ & $400(360,440)$ & $360(320,400)$ \\
\hline & + & $360(320,390) *$ & $500(450,540) *$ & $290(260,320) *$ \\
\hline & & \multicolumn{3}{|c|}{$\begin{array}{c}\mathrm{G}: \mathrm{F}=2.4, p=0.125 ; \mathrm{S}: \mathrm{F}=18.7, p<0.001 ; \mathrm{G} \times \mathrm{S}(\mathrm{WP}): \mathrm{F}=7.3, p=0.001 ; \mathrm{GDM}-\mathrm{b}>\mathrm{a}, \mathrm{c}>\mathrm{a} ; \mathrm{GDM}+\mathrm{b}>\mathrm{a}, \\
\mathrm{c}<\mathrm{a}, \mathrm{c}<\mathrm{b}\end{array}$} \\
\hline
\end{tabular}


Table 1. Cont.

\begin{tabular}{|c|c|c|c|c|}
\hline \multirow{2}{*}{ Steroid } & \multirow{2}{*}{ GDM } & \multicolumn{3}{|c|}{ GDM $\times$ Stage } \\
\hline & & Week 24-28 of Gestation (a) & Week $30-36$ of Gestation (b) & Labor (c) \\
\hline \multirow{3}{*}{$\begin{array}{l}\text { Conjugated } \\
17 \alpha, 20 \alpha \text {-dihydroxy-4- } \\
\text { pregnen-3-one }[\mathrm{nM}]\end{array}$} & - & $3.6(3.1,4.3)$ & $4.6(3.9,5.5)$ & $9.4(7.9,11)$ \\
\hline & + & $2.7(2.3,3.2)$ & $3.2(2.7,3.7) *$ & $6.2(5.2,7.3) *$ \\
\hline & & \multicolumn{3}{|c|}{$\mathrm{G}(\mathrm{WP}): \mathrm{F}=15.4, p<0.001 ; \mathrm{S}: \mathrm{F}=34.3, p<0.001 ; \mathrm{G} \times \mathrm{S}: \mathrm{F}=0.1, p=0.876 ; \mathrm{GDM}-\mathrm{c}>\mathrm{a}, \mathrm{c}>\mathrm{b} ; \mathrm{GDM}+\mathrm{c}>\mathrm{a}, \mathrm{c}>\mathrm{b}$} \\
\hline \multirow{3}{*}{$\begin{array}{l}20 \alpha- \\
\text { Dihydroprogesterone } \\
{[\mathrm{nM}]}\end{array}$} & \multirow{3}{*}{$\begin{array}{l}- \\
+\end{array}$} & $49(46,53)$ & $85(79,92)$ & $120(110,130)$ \\
\hline & & \multirow{2}{*}{\multicolumn{3}{|c|}{$\begin{array}{c}\mathrm{G}(\mathrm{UP}): \mathrm{F}=8, p=0.006 ; \mathrm{S}: \mathrm{F}=142, p<0.001 ; \mathrm{G} \times \mathrm{S}(\mathrm{WP}): \mathrm{F}=6.3, p=0.003 ; \mathrm{GDM}-\mathrm{b}>\mathrm{a}, \mathrm{c}>\mathrm{a}, \mathrm{c}>\mathrm{b} ; \\
\mathrm{GDM}+\mathrm{b}>\mathrm{a}, \mathrm{c}>\mathrm{a}, \mathrm{c}>\mathrm{b}\end{array}$}} \\
\hline & & & & \\
\hline \multirow{3}{*}{ Testosterone [nM] } & \multirow{3}{*}{$\begin{array}{l}- \\
+\end{array}$} & $2.3(2.1,2.5)$ & $2.5(2.3,2.7)$ & $3.6(3.3,4)$ \\
\hline & & $2(1.8,2.2)$ & $2(1.8,2.1) *$ & $3.1(2.8,3.4)$ \\
\hline & & \multicolumn{3}{|c|}{$\mathrm{G}(\mathrm{WP}): \mathrm{F}=12.8, p<0.001 ; \mathrm{S}: \mathrm{F}=32.8, p<0.001 ; \mathrm{G} \times \mathrm{S}: \mathrm{F}=0.3, p=0.723 ; \mathrm{GDM}-\mathrm{c}>\mathrm{a}, \mathrm{c}>\mathrm{b} ; \mathrm{GDM}+\mathrm{c}>\mathrm{a}, \mathrm{c}>\mathrm{b}$} \\
\hline \multirow{3}{*}{$\begin{array}{l}16 \alpha- \\
\text { Hydroxytestosterone } \\
{[\mathrm{nM}]}\end{array}$} & \multirow{3}{*}{$\begin{array}{l}- \\
+\end{array}$} & $4.9(3.8,6.1)$ & $8.2(6.7,9.9)$ & $9.3(7.7,11)$ \\
\hline & & $3.5(2.6,4.5)$ & $6.6(5.4,8.1)$ & $6.5(5.2,7.9)$ \\
\hline & & \multicolumn{3}{|c|}{$\mathrm{G}(\mathrm{UP}): \mathrm{F}=6.5, p=0.012 ; \mathrm{S}: \mathrm{F}=11.3, p<0.001 ; \mathrm{G} \times \mathrm{S}: \mathrm{F}=0.2, p=0.848 ; \mathrm{GDM}-\mathrm{b}>\mathrm{a}, \mathrm{c}>\mathrm{a} ; \mathrm{GDM}+\mathrm{b}>\mathrm{a}, \mathrm{c}>\mathrm{a}$} \\
\hline \multirow{3}{*}{ Estrone sulfate $[\mathrm{nM}]$} & \multirow{3}{*}{$\begin{array}{l}- \\
+\end{array}$} & $96(77,120)$ & $110(87,140)$ & $190(150,240)$ \\
\hline & & & $98(79,120)$ & $120(97,150) *$ \\
\hline & & \multicolumn{3}{|c|}{$\mathrm{G}(\mathrm{UP}): \mathrm{F}=5.6, p=0.02 ; \mathrm{S}: \mathrm{F}=8.9, p<0.001 ; \mathrm{G} \times \mathrm{S}: \mathrm{F}=0.6, p=0.528 ; \mathrm{GDM}-\mathrm{c}>\mathrm{a}, \mathrm{c}>\mathrm{b} ; \mathrm{GDM}+\mathrm{c}>\mathrm{a}$} \\
\hline \multirow{3}{*}{ Estradiol [nM] } & \multirow{3}{*}{$\begin{array}{l}- \\
+\end{array}$} & $66(54,79)$ & $90(74,110)$ & $66(54,80)$ \\
\hline & & $47(38,57)$ & $71(58,85)$ & $48(40,59)$ \\
\hline & & \multicolumn{3}{|c|}{$\mathrm{G}(\mathrm{UP}): \mathrm{F}=7, p=0.009 ; \mathrm{S}: \mathrm{F}=4.8, p=0.01 ; \mathrm{G} \times \mathrm{S}: \mathrm{F}=0.1, p=0.945 ; \mathrm{GDM}+\mathrm{b}>\mathrm{a}$} \\
\hline & - & $34(29,39)$ & $49(42,56)$ & $55(48,63)$ \\
\hline Estradiol sulfate [nM] & + & $25(22,29) *$ & $36(31,41) *$ & $30(26,34) *$ \\
\hline & & $\mathrm{G}(\mathrm{WP}): \mathrm{F}=26.4, p<0.001 ; \mathrm{S}: \mathrm{F}$ & $p<0.001 ; \mathrm{G} \times \mathrm{S}: \mathrm{F}=1.8, p=0.1$ & $>a, c>a ; G D M+b>a$ \\
\hline & - & $170(150,200)$ & $280(240,320)$ & $360(310,410)$ \\
\hline & + & $120(100,130) *$ & $170(150,200) *$ & $280(250,330)$ \\
\hline Estriol sulfate [nIM] & & $\mathrm{G}(\mathrm{WP}): \mathrm{F}=20.4, p<0.001 ; \mathrm{S}: \mathrm{F}=$ & $\begin{array}{c}p<0.001 ; \mathrm{G} \times \mathrm{S}: \mathrm{F}=0.9, p=0 . \\
\mathrm{c}>\mathrm{a}, \mathrm{c}>\mathrm{b}\end{array}$ & $>a, c>a ; G D M+b>a$ \\
\hline & - & $0.84(0.76,0.92)$ & $1.1(1,1.2)$ & $1.2(1.1,1.3)$ \\
\hline Allopregnanolone & + & $0.58(0.53,0.63)$ * & $0.98(0.9,1.1)$ & $1.1(1,1.2)$ \\
\hline sulfate $[\mu \mathrm{M}]$ & & $\mathrm{G}(\mathrm{WP}): \mathrm{F}=14.5, p<0.001 ;$ & $\begin{array}{c}37.4, p<0.001 ; \mathrm{G} \times \mathrm{S}: \mathrm{F}=3.3(\mathrm{~W} \\
\mathrm{GDM}+\mathrm{b}>\mathrm{a}, \mathrm{c}>\mathrm{a}\end{array}$ & $G D M-b>a, c>a$ \\
\hline & - & $470(420,520)$ & $610(550,690)$ & $750(670,840)$ \\
\hline Isopregnanolone & + & $330(300,370)$ * & $550(490,610)$ & $630(560,700)$ \\
\hline & & $\mathrm{G}(\mathrm{UP}): \mathrm{F}=11.3, p=0.001 ; \mathrm{S}: \mathrm{F}=2$ & $0.001 ; \mathrm{G} \times \mathrm{S}: \mathrm{F}=1.2, p=0.301$ & c c > a; GDM+b $>a, c>a$ \\
\hline & - & $480(440,530)$ & $640(580,700)$ & $690(630,770)$ \\
\hline Conjugated & + & $380(350,420) *$ & $640(580,700)$ & $780(710,870)$ \\
\hline pregnanolone [nM] & & $\mathrm{G}: \mathrm{F}=0.6, p=0.439 ; \mathrm{S}: \mathrm{F}=40.2, p$ & $\begin{array}{c}01 ; \mathrm{G} \times \mathrm{S}(\mathrm{WP}): \mathrm{F}=4, p=0.021 \\
\mathrm{c}>\mathrm{b}\end{array}$ & $c>a ; G D M+b>a, c>a$, \\
\hline & - & $130(120,140)$ & $160(150,180)$ & $200(180,220)$ \\
\hline $\begin{array}{l}\text { Conjugated } \\
\text { epinreonanolone [nMl }\end{array}$ & + & $97(88,110) *$ & $140(130,160)$ & $160(140,170)$ * \\
\hline & & $\mathrm{G}(\mathrm{WP}): \mathrm{F}=14.3, p<0.001 ; \mathrm{S}: \mathrm{F}=2$ & $<0.001 ; \mathrm{G} \times \mathrm{S}: \mathrm{F}=0.6, p=0.559$ & $a, c>a ; G D M+b>a, c>a$ \\
\hline & - & $8.1(7.5,8.7)$ & $11(9.8,11)$ & $14(13,15)$ \\
\hline Conjugated $5 \alpha$-pregnane- & + & $6.1(5.7,6.5)^{*}$ & $9.3(8.7,10)$ & $12(11,13)$ \\
\hline $3 \alpha, 20 \alpha$-diol $[\mu \mathrm{M}]$ & & $\mathrm{G}(\mathrm{WP}): \mathrm{F}=20, p<0.001 ; \mathrm{S}: \mathrm{F}=7$ & $\begin{array}{c}0.001 ; \mathrm{G} \times \mathrm{S}: \mathrm{F}=1.7, p=0.194 \\
\mathrm{c}>\mathrm{a}, \mathrm{c}>\mathrm{b}\end{array}$ & $>a, c>b ; G D M+b>a$ \\
\hline & - & $19(17,20)$ & $26(24,29)$ & $31(29,34)$ \\
\hline Conjugated $5 \alpha$-pregnane- & + & $15(14,17)$ * & $23(21,25)$ & $28(26,30)$ \\
\hline $3 \beta, 20 \alpha-\operatorname{diol}[\mu \mathrm{M}]$ & & $\mathrm{G}(\mathrm{UP}): \mathrm{F}=10.8, p=0.001 ; \mathrm{S}$ & $\begin{array}{c}51.2, p<0.001 ; \mathrm{G} \times \mathrm{S}: \mathrm{F}=0.3, p \\
\mathrm{GDM}+\mathrm{b}>\mathrm{a}, \mathrm{c}>\mathrm{a}, \mathrm{c}>\mathrm{b}\end{array}$ & $-b>a, c>a, c>b$ \\
\hline & - & $5.8(5.4,6.3)$ & $7.4(6.8,8.1)$ & $7.3(6.7,8)$ \\
\hline 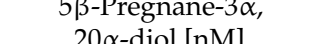 & + & $7.2(6.7,7.9)$ * & $8.8(8,9.6)$ & $7.1(6.5,7.7)$ \\
\hline & & $\mathrm{G}(\mathrm{UP}): \mathrm{F}=6.2, p=0.014 ; \mathrm{S}: \mathrm{F}=7$ & $0.001 ; \mathrm{G} \times \mathrm{S}: \mathrm{F}=2.7, p=0.073$ &,$c>a ; G D M+b>a, c<b$ \\
\hline $17-$ & - & $0.34(0.29,0.4)$ & $0.54(0.46,0.63)$ & $0.59(0.51,0.68)$ \\
\hline Hydroxyallopregnanolone & + & $0.17(0.15,0.2) *$ & $0.39(0.33,0.45)$ * & $0.38(0.33,0.44) *$ \\
\hline$[\mathrm{nM}]$ & & $\mathrm{G}(\mathrm{WP}): \mathrm{F}=30.5, p<0.001 ; \mathrm{S}: \mathrm{F}=$ & $<0.001 ; \mathrm{G} \times \mathrm{S}: \mathrm{F}=1, p=0.357$ & $c>a ; G D M+b>a, c>a$ \\
\hline & - & $11(10,12)$ & $17(15,18)$ & $22(20,24)$ \\
\hline Hydroxyallopregnanolone & + & $8(7.5,8.7)$ * & $13(12,14)$ * & $18(17,20)$ \\
\hline $\begin{array}{l}\text { Hyaroxyallopregnanoione } \\
\text { sulfate }[\mathrm{nM}]\end{array}$ & & $\mathrm{G}(\mathrm{WP}): \mathrm{F}=28.7, p<0.001 ; \mathrm{S}$ & $\begin{array}{c}\text { 78.9, } p<0.001 ; \mathrm{G} \times \mathrm{S}: \mathrm{F}=1.5, p \\
\mathrm{GDM}+\mathrm{b}>\mathrm{a}, \mathrm{c}>\mathrm{a}, \mathrm{c}>\mathrm{b}\end{array}$ & $-b>a, c>a, c>b$ \\
\hline
\end{tabular}


Table 1. Cont.

\begin{tabular}{|c|c|c|c|c|}
\hline \multirow{2}{*}{ Steroid } & \multirow{2}{*}{ GDM } & \multicolumn{3}{|c|}{ GDM $\times$ Stage } \\
\hline & & Week $24-28$ of Gestation (a) & Week $30-36$ of Gestation (b) & Labor (c) \\
\hline \multirow{3}{*}{$\begin{array}{c}17- \\
\text { Hydroxypregnanolone } \\
{[\mathrm{nM}]}\end{array}$} & - & $0.81(0.72,0.89)$ & $1(0.92,1.1)$ & $1.2(1.1,1.4)$ \\
\hline & + & $0.68(0.61,0.75)$ & $0.91(0.82,1)$ & $0.91(0.82,1) *$ \\
\hline & & \multicolumn{3}{|c|}{$\begin{array}{c}\mathrm{G}(\mathrm{UP}): \mathrm{F}=12.2, p<0.001 ; \mathrm{S}: \mathrm{F}=14.8, p<0.001 ; \mathrm{G} \times \mathrm{S}: \mathrm{F}=1.2, p=0.294 ; \mathrm{GDM}-\mathrm{b}>\mathrm{a}, \mathrm{c}>\mathrm{a}, \mathrm{c}>\mathrm{b} ; \mathrm{GDM}+ \\
\mathrm{b}>\mathrm{a}, \mathrm{c}>\mathrm{a}\end{array}$} \\
\hline \multirow{3}{*}{$\begin{array}{l}\text { Conjugated 17-hydroxy- } \\
\text { pregnanolone [nM] }\end{array}$} & - & $44(40,48)$ & $68(62,74)$ & $110(96,120)$ \\
\hline & + & $38(36,41)$ & $58(53,63)$ & $95(86,100)$ \\
\hline & & \multicolumn{3}{|c|}{$\begin{array}{c}\mathrm{G}(\mathrm{UP}): \mathrm{F}=8, p=0.006 ; \mathrm{S}: \mathrm{F}=121.1, p<0.001 ; \mathrm{G} \times \mathrm{S}: \mathrm{F}=0.2, p=0.854 ; \mathrm{GDM}-\mathrm{b}>\mathrm{a}, \mathrm{c}>\mathrm{a}, \mathrm{c}>\mathrm{b} ; \mathrm{GDM}+\mathrm{b}>\mathrm{a} \\
\mathrm{c}>\mathrm{a}, \mathrm{c}>\mathrm{b}\end{array}$} \\
\hline \multirow{3}{*}{$\begin{array}{l}5 \alpha \text {-Pregnane- } 3 \alpha, 17 \alpha, \\
\quad 20 \alpha \text {-triol }[\mathrm{nM}]\end{array}$} & - & $0.18(0.15,0.21)$ & $0.19(0.16,0.22)$ & $0.25(0.21,0.29)$ \\
\hline & + & $0.1(0.089,0.12) *$ & $0.15(0.13,0.18)$ & $0.18(0.15,0.21)$ * \\
\hline & & \multicolumn{3}{|c|}{$\mathrm{G}(\mathrm{WP}): \mathrm{F}=15.5, p<0.001 ; \mathrm{S}: \mathrm{F}=8.4, p<0.001 ; \mathrm{G} \times \mathrm{S}: \mathrm{F}=1.2, p=0.296 ; \mathrm{GDM}-\mathrm{c}>\mathrm{a} ; \mathrm{GDM}+\mathrm{b}>\mathrm{a}, \mathrm{c}>\mathrm{a}$} \\
\hline \multirow{3}{*}{$\begin{array}{l}5 \alpha \text {-Pregnane- } 3 \beta, 17 \alpha, \\
\quad 20 \alpha \text {-triol }[\mathrm{pM}]\end{array}$} & - & $110(90,130)$ & $130(120,160)$ & $150(130,170)$ \\
\hline & + & $73(61,87) *$ & $110(92,130)$ & $110(96,130)$ \\
\hline & & \multicolumn{3}{|c|}{$\mathrm{G}(\mathrm{UP}): \mathrm{F}=10.1, p=0.002 ; \mathrm{S}: \mathrm{F}=6.5, p=0.002 ; \mathrm{G} \times \mathrm{S}: \mathrm{F}=0.2, p=0.829 ; \mathrm{GDM}-\mathrm{c}>\mathrm{a} ; \mathrm{GDM}+\mathrm{b}>\mathrm{a}, \mathrm{c}>\mathrm{a}$} \\
\hline \multirow{3}{*}{$\begin{array}{l}\text { Conjugated } 5 \alpha \text {-pregnane- } \\
3 \beta, 17 \alpha, 20 \alpha \text {-triol }[\mathrm{nM}]\end{array}$} & - & $3.6(2.8,4.5)$ & $5.2(4.1,6.7)$ & $7.7(6,9.9)$ \\
\hline & + & $2.1(1.7,2.7)$ * & $2.8(2.2,3.5) *$ & $6.2(4.8,8.1)$ \\
\hline & & \multicolumn{3}{|c|}{$\mathrm{G}(\mathrm{UP}): \mathrm{F}=10.9, p=0.001 ; \mathrm{S}: \mathrm{F}=16.1, p<0.001 ; \mathrm{G} \times \mathrm{S}: \mathrm{F}=0.9, p=0.393 ; \mathrm{GDM}-\mathrm{c}>\mathrm{a} ; \mathrm{GDM}+\mathrm{c}>\mathrm{a}, \mathrm{c}>\mathrm{b}$} \\
\hline \multirow{3}{*}{$\begin{array}{l}5 \beta \text {-Pregnane- } 3 \alpha, 17 \alpha, \\
\quad 20 \alpha \text {-triol }[\mathrm{nM}]\end{array}$} & - & $3.1(2.7,3.4)$ & $3.4(3,3.8)$ & $4.5(4,5)$ \\
\hline & + & $2.4(2.1,2.7) *$ & $3.3(2.9,3.7)$ & $3.9(3.4,4.3)$ \\
\hline & & \multicolumn{3}{|c|}{$\mathrm{G}(\mathrm{UP}): \mathrm{F}=4.7, p=0.032 ; \mathrm{S}: \mathrm{F}=15.5, p<0.001 ; \mathrm{G} \times \mathrm{S}: \mathrm{F}=1.1, p=0.334 ; \mathrm{GDM}-\mathrm{c}>\mathrm{a}, \mathrm{c}>\mathrm{b} ; \mathrm{GDM}+\mathrm{b}>\mathrm{a}, \mathrm{c}>\mathrm{a}$} \\
\hline \multirow{3}{*}{$\begin{array}{l}\text { Conjugated } 5 \beta \text {-pregnane- } \\
3 \alpha, 17 \alpha, 20 \alpha \text {-triol [nM] }\end{array}$} & \multirow{3}{*}{$\begin{array}{l}- \\
+\end{array}$} & $250(220,290)$ & $380(330,440)$ & $890(740,1100)$ \\
\hline & & $230(200,270)$ & $270(240,310)^{*}$ & $500(430,590)^{*}$ \\
\hline & & \multicolumn{3}{|c|}{$\begin{array}{c}\mathrm{G}(\mathrm{WP}): \mathrm{F}=13.5, p<0.001 ; \mathrm{S}: \mathrm{F}=47.2, p<0.001 ; \mathrm{G} \times \mathrm{S}: \mathrm{F}=2.1, p=0.131 ; \mathrm{GDM}-\mathrm{b}>\mathrm{a}, \mathrm{c}>\mathrm{a}, \mathrm{c}>\mathrm{b} \\
\mathrm{GDM}+\mathrm{c}>\mathrm{a}, \mathrm{c}>\mathrm{b}\end{array}$} \\
\hline \multirow{3}{*}{ Androsterone [nM] } & \multirow{3}{*}{+} & $0.46(0.43,0.5)$ & $0.52(0.48,0.56)$ & $0.63(0.58,0.69)$ \\
\hline & & $0.39(0.36,0.43)$ * & $0.45(0.41,0.48)$ & $0.53(0.49,0.58)$ * \\
\hline & & $\mathrm{G}(\mathrm{UP}): \mathrm{F}=12.3, p<0.001 ; \mathrm{S}: \mathrm{F}=1$ & $<0.001 ; \mathrm{G} \times \mathrm{S}: \mathrm{F}=0, p=0.979$ & $a, c>b ; G D M+c>a, c>b$ \\
\hline & - & $110(110,120)$ & $100(96,110)$ & $130(130,140)$ \\
\hline Epiandrosterone & + & $110(100,120)$ & $93(88,98)$ & $120(110,130)$ \\
\hline & & $\mathrm{G}(\mathrm{UP}): \mathrm{F}=4.9, p=0.029 ; \mathrm{S}: \mathrm{F}=26$ & $0.001 ; \mathrm{G} \times \mathrm{S}: \mathrm{F}=0.9, p=0.409$ & $\mathrm{a}, \mathrm{c}>\mathrm{b} ; \mathrm{GDM}+\mathrm{b}<\mathrm{a}, \mathrm{c}>\mathrm{b}$ \\
\hline & - & $31(29,34)$ & $30(27,33)$ & $42(39,46)$ \\
\hline Etiocholanolone & + & $36(33,40)$ & $32(29,35)$ & $50(46,55)$ \\
\hline & & $\mathrm{G}(\mathrm{UP}): \mathrm{F}=6.7, p=0.011 ; \mathrm{S}: \mathrm{F}=23$ & $0.001 ; \mathrm{G} \times \mathrm{S}: \mathrm{F}=0.3, p=0.722$ & $a, c>b ; G D M+c>a, c>b$ \\
\hline & - & $0.14(0.13,0.15)$ & $0.16(0.15,0.18)$ & $0.18(0.16,0.19)$ \\
\hline $5 \alpha$-Androstane- $3 \alpha$ & + & $0.14(0.13,0.15)$ & $0.15(0.14,0.16)$ & $0.14(0.13,0.15)$ * \\
\hline 17ß-diol [nM] & & $\mathrm{G}(\mathrm{WP}): \mathrm{F}=9.4, p=$ & $\mathrm{F}=2.3, p=0.103 ; \mathrm{G} \times \mathrm{S}: \mathrm{F}=2$ & $\mathrm{GDM}-\mathrm{c}>\mathrm{a}$ \\
\hline & - & $11(10,12)$ & $16(14,18)$ & $32(28,36)$ \\
\hline Conjugated & + & $8.1(7.4,8.9) *$ & $11(10,12) *$ & $22(19,24) *$ \\
\hline $\begin{array}{c}5 \alpha \text {-androstane- } \\
3 \alpha, 17 \beta \text {-diol }[\mathrm{nM}]\end{array}$ & & $\mathrm{G}(\mathrm{WP}): \mathrm{F}=36.6, p<0.001 ; \mathrm{S}: \mathrm{F}=$ & $\begin{array}{l}0.001 ; \mathrm{G} \times \mathrm{S}: \mathrm{F}=0, p=0.972 \\
\qquad \mathrm{c}>\mathrm{a}, \mathrm{c}>\mathrm{b}\end{array}$ & $c>a, c>b ; G D M+b>a$, \\
\hline & - & $110(92,130)$ & $110(90,130)$ & $100(87,120)$ \\
\hline $5 \alpha$-Androstane- & + & $82(69,97)$ & $87(74,100)$ & $91(77,110)$ \\
\hline $3[3,17 \beta-\mathrm{d} 10 \mathrm{l}[\mathrm{pl}]]$ & & $\mathrm{G}(\mathrm{UP}): \mathrm{F}=4$ & $0.036 ; \mathrm{S}: \mathrm{F}=0, p=0.975 ; \mathrm{G} \times \mathrm{S}$ & 0.792 \\
\hline Conjugated & - & $10(9,12)$ & $13(12,15)$ & $20(17,23)$ \\
\hline $5 \alpha$-androstane- & + & $7.9(7,8.9)$ * & $8.7(7.7,9.9)$ * & $14(13,16) *$ \\
\hline $3 \beta, 17 \beta-\operatorname{diol}[\mathrm{nM}]$ & & $\mathrm{G}(\mathrm{WP}): \mathrm{F}=20.8, p<0.001 ; \mathrm{S}: \mathrm{F}=$ & $0.001 ; \mathrm{G} \times \mathrm{S}: \mathrm{F}=0.4, p=0.67$ & $a, c>b ; G D M+c>a, c>b$ \\
\hline Conjugated & - & $0.68(0.56,0.83)$ & $0.84(0.69,1)$ & $1.2(1,1.5)$ \\
\hline $5 \beta$-androstane- & + & $0.46(0.38,0.55)$ * & $0.43(0.36,0.52)$ * & $0.73(0.6,0.89)$ * \\
\hline $3 \beta, 17 \beta$-diol $[\mathrm{nM}]$ & & $\mathrm{G}(\mathrm{WP}): \mathrm{F}=24.3, p<0.001 ; \mathrm{S}: \mathrm{F}=1$ & $0.001 ; \mathrm{G} \times \mathrm{S}: \mathrm{F}=0.6, p=0.57$ & $a, c>b ; G D M+c>a, c>b$ \\
\hline & - & $150(140,160)$ & $180(170,200)$ & $210(200,230)$ \\
\hline Cortisone $[\mathrm{nM}]$ & + & $140(130,160)$ & $170(150,180)$ & $180(160,190)$ * \\
\hline & & $\mathrm{G}(\mathrm{UP}): \mathrm{F}=6, p=0.016 ; \mathrm{S}: \mathrm{F}$ & $0.001 ; \mathrm{G} \times \mathrm{S}: \mathrm{F}=1.1, p=0.34$ & $>a, c>a ; G D M+c>a$ \\
\hline & - & $0.64(0.47,0.86)$ & $0.99(0.75,1.3)$ & $1.2(0.92,1.6)$ \\
\hline 11-Deoxycorticosterone & + & $0.3(0.21,0.41)$ * & $0.82(0.62,1.1)$ & $1.1(0.8,1.4)$ \\
\hline & & $\mathrm{G}(\mathrm{UP}): \mathrm{F}=4.5, p=0.037 ; \mathrm{S}: \mathrm{F}=$ & $p<0.001 ; \mathrm{G} \times \mathrm{S}: \mathrm{F}=1.2, p=0.3$ & $>a ; G D M+b>a, c>a$ \\
\hline
\end{tabular}


Table 1. Cont.

\begin{tabular}{|c|c|c|c|c|}
\hline \multirow{2}{*}{ Steroid } & \multirow{2}{*}{ GDM } & \multicolumn{3}{|c|}{ GDM $\times$ Stage } \\
\hline & & Week $24-28$ of Gestation (a) & Week $30-36$ of Gestation (b) & Labor (c) \\
\hline \multirow{3}{*}{$\begin{array}{c}\text { Conjugated } \\
\text { 11-deoxycorticosterone } \\
{[\mathrm{nM}]}\end{array}$} & - & $5.2(4.1,6.5)$ & $5(4,6.3)$ & $6.4(5.1,8.2)$ \\
\hline & + & $3.5(2.8,4.3)$ & $3.9(3.1,4.8)$ & $4.8(3.8,6.1)$ \\
\hline & & \multicolumn{3}{|c|}{$\mathrm{G}(\mathrm{UP}): \mathrm{F}=5.9, p=0.017 ; \mathrm{S}: \mathrm{F}=1.8, p=0.164 ; \mathrm{G} \times \mathrm{S}: \mathrm{F}=0.1, p=0.886$} \\
\hline \multirow{3}{*}{$\begin{array}{c}3 \alpha, 5 \alpha- \\
\text { Tetrahydrocorticosterone } \\
{[\mathrm{pM}]}\end{array}$} & - & $38(27,54)$ & $35(25,49)$ & $150(110,220)$ \\
\hline & + & $55(40,77)$ & $65(47,91)$ & $190(140,280)$ \\
\hline & & \multicolumn{3}{|c|}{$\mathrm{G}(\mathrm{UP}): \mathrm{F}=4.2, p=0.043 ; \mathrm{S}: \mathrm{F}=20.7, p<0.001 ; \mathrm{G} \times \mathrm{S}: \mathrm{F}=0.4, p=0.67 ; \mathrm{GDM}-\mathrm{c}>\mathrm{a}, \mathrm{c}>\mathrm{b} ; \mathrm{GDM}+\mathrm{c}>\mathrm{a}, \mathrm{c}>\mathrm{b}$} \\
\hline \multirow{3}{*}{$\begin{array}{c}11 \beta- \\
\text { Hydroxyandrosterone } \\
{[\mathrm{nM}]}\end{array}$} & - & $0.5(0.43,0.57)$ & $0.47(0.41,0.54)$ & $0.94(0.84,1.1)$ \\
\hline & + & $0.31(0.27,0.35)$ * & $0.27(0.23,0.3)$ * & $0.64(0.57,0.73)$ * \\
\hline & & \multicolumn{3}{|c|}{$\mathrm{G}(\mathrm{WP}): \mathrm{F}=43.7, p<0.001 ; \mathrm{S}: \mathrm{F}=55.8, p<0.001 ; \mathrm{G} \times \mathrm{S}: \mathrm{F}=0.6, p=0.581 ; \mathrm{GDM}-\mathrm{c}>\mathrm{a}, \mathrm{c}>\mathrm{b} ; \mathrm{GDM}+\mathrm{c}>\mathrm{a}, \mathrm{c}>\mathrm{b}$} \\
\hline \multirow{3}{*}{$\begin{array}{c}11 \beta- \\
\text { Hydroxyandrosterone } \\
\text { sulfate }[\mathrm{nM}]\end{array}$} & - & $8.5(7.8,9.3)$ & $9.7(8.9,11)$ & $13(12,14)$ \\
\hline & + & $6.2(5.7,6.7) *$ & $8(7.4,8.8)$ * & $12(11,13)$ \\
\hline & & \multicolumn{3}{|c|}{$\begin{array}{c}\mathrm{G}(\mathrm{WP}): \mathrm{F}=18.1, p<0.001 ; \mathrm{S}: \mathrm{F}=38.6, p<0.001 ; \mathrm{G} \times \mathrm{S}: \mathrm{F}=1.7, p=0.195 ; \mathrm{GDM}-\mathrm{c}>\mathrm{a}, \mathrm{c}>\mathrm{b} ; \mathrm{GDM}+\mathrm{b}>\mathrm{a}, \\
\mathrm{c}>\mathrm{a}, \mathrm{c}>\mathrm{b}\end{array}$} \\
\hline \multirow{3}{*}{$\begin{array}{c}11 \beta- \\
\text { Hydroxyepiandrosterone } \\
{[\mathrm{pM}]}\end{array}$} & - & $14(11,18)$ & $18(14,23)$ & $52(41,66)$ \\
\hline & + & $7.3(5.5,9.6)$ * & $12(8.9,15)$ & $37(29,46)$ \\
\hline & & \multicolumn{3}{|c|}{$\mathrm{G}(\mathrm{UP}): \mathrm{F}=10.5, p=0.002 ; \mathrm{S}: \mathrm{F}=41, p<0.001 ; \mathrm{G} \times \mathrm{S}: \mathrm{F}=0.3, p=0.721 ; \mathrm{GDM}-\mathrm{c}>\mathrm{a}, \mathrm{c}>\mathrm{b} ; \mathrm{GDM}+\mathrm{c}>\mathrm{a}, \mathrm{c}>\mathrm{b}$} \\
\hline
\end{tabular}

ANOVA model: G: . . f factor GDM (GDM+vs. GDM-); S: . . factor Stage, G $\times$ S: . . GDM $\times$ Stage interaction, F $=$ F-statistic, $p=p$ value, * represents a significant difference between GDM+ and GDM- subgroups $(p<0.05)$, a, b, and c symbolize stages Week 24-28, Week $30-36$, and Labor, respectively, only significant differences between stages are shown $(p<0.05)$, WP ... well-powered analysis, UP ... underpowered analysis.

\subsection{Terminology of Steroid Polar Conjugates}

The term steroid sulfate was used in the case of the dominance of $3 \alpha / \beta$-monosulfate over other forms of steroid conjugates, while the term conjugated steroid was used in the case of comparable amounts of conjugate forms (sulfates, disulfates, and glucuronides). This terminology was based on the relevant literature, with appropriate citations for each steroid as follows: pregnenolone sulfate (PregS) [40,41], 20 $\alpha$-dihydropregnenolone sulfate, dehydroepiandrosterone sulfate (DHEAS) [41-43], 16 $\alpha$-hydroxy-DHEA sulfate [41,44], androstenediol sulfate [41,42], allopregnanolone sulfate [45], isopregnanolone sulfate [46], conjugated pregnanolone (sulfate + glucuronide [45]), $5 \alpha$-pregnane- $3 \beta, 20 \alpha$-diol sulfate $(3 \beta, 20 \alpha$-disulfate $+3 \beta$-sulfate) [45], conjugated $5 \beta$-pregnane-3 $\alpha, 20 \alpha$-diol $(3 \beta, 20 \alpha$-disulfate $+3 \beta$-sulfate + glucuronide) [45], androsterone sulfate [41,42], epiandrosterone sulfate [41,42], etiocholanolone sulfate [44], epietiocholanolone sulfate, conjugated $5 \alpha$-androstane- $3 \alpha, 17 \beta$ diol (sulfate + glucuronide [42]), and conjugated $5 \alpha$-androstane- $3 \beta, 17 \beta$-diol (sulfate + glucuronide [42]).

\subsection{Statistical Analysis}

The data processing for steroid levels in the samples of mixed umbilical blood at labor was carried out using an ANOVA model consisting of factors GDM (+/ -), Gender (of the newborn) (F/M), and Thyropathy $(+/-)$ (in mother). The factors Gender and Thyropathy were included for adjustment as levels of some steroids depended on these factors and their effect should be separated from the effect of GDM. The evaluation of steroid levels in the samples of blood from the maternal cubital vein in three stages of the study was completed using an ANOVA model consisting of factors Subject explaining the inter-individual variability, between-subject factor GDM (+/-), within-subject factor Stage (of the study) (week 24-28 of gestation, week 30-36 of gestation, labor), interaction GDM $\times$ Stage, and between-subject factors for the adjustment Gender (F/M) and Thyropathy $(+/-)$. The ANOVA testing was followed by Bonferroni multiple comparisons. The level of statistical significance was set to $p<0.05$.

Respecting the skewed data distribution and non-constant variance in most dependent variables, these were transformed by power transformations to achieve data symmetry and homoscedasticity prior to further data processing [47]. The homogeneity and distribution of the transformed data were checked by residual analysis as described elsewhere [48]. The statistical software Statgraphics Centurion 18 Version 18.1.06 from Statgraphics Technolo- 
gies, Inc. (The Plains, VA, USA) was used for the statistical analysis. Due to the absence of preliminary data for 101 steroids and limited sample size, the power analysis based on the F-test was completed post hoc. In the case of significant factor GDM and/or significant GDM $\times$ Stage interaction, the well-powered analyses (WP) and underpowered analyses (UP) were added in corresponding tables. For the WP analyses, the $p$-value was set to 0.05 and power to 0.8 . The power analysis was performed using PASS 16 Power Analysis and Sample Size Software (2018) from NCSS, LLC. (Kaysville, UT, USA).

\section{Results}

\subsection{GDM and Steroidome in the Mixed Umbilical Blood after Delivery of Placenta and Fetus}

Only four significant GDM-related steroid changes were found in the mixed umbilical cord blood, such as lower levels of $5 \alpha / \beta$ - and 20-oxo/20 $\alpha$-reduced metabolites of 17 hydroxyprogesterone and conjugated $5 \alpha$-androstane- $3 \alpha, 17 \alpha$-diol indicating lower activity of the CYP17A1, particularly in the 17-hydroxylase step (see Figure 1 and Table S2).
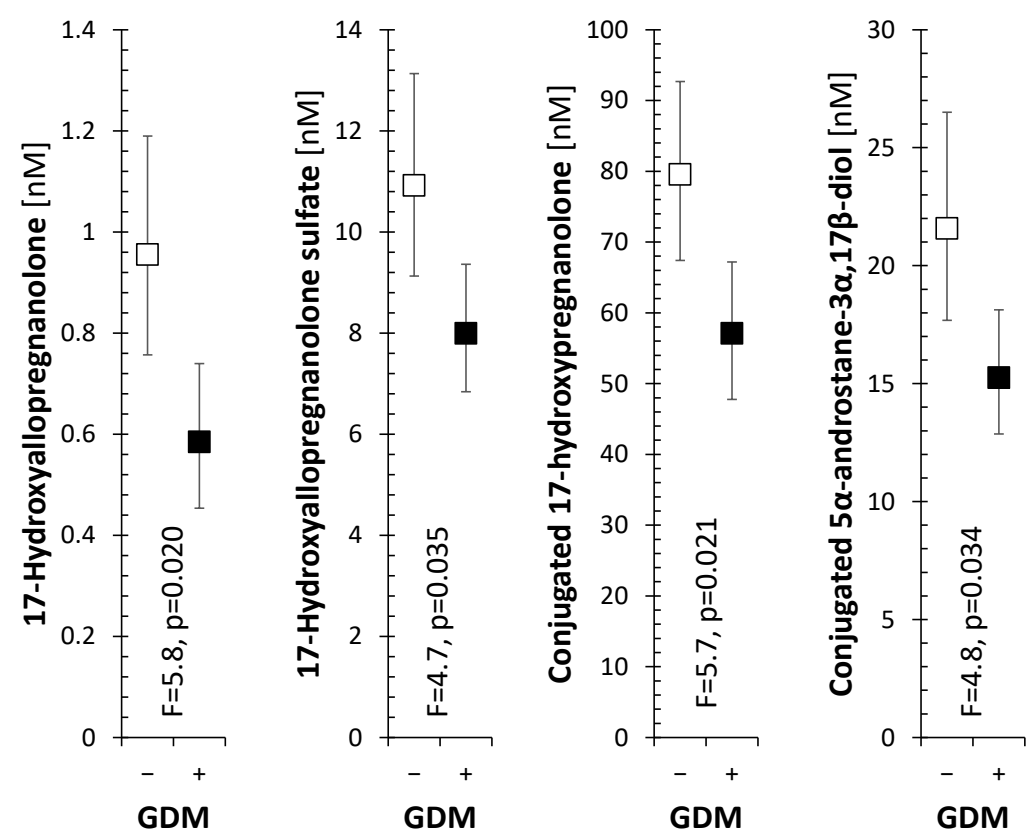

Figure 1. Levels of steroids showing significant differences between GDM- and GDM+ groups in mixed umbilical cord blood as evaluated by ANOVA adjusted to sex of the fetus and presence of thyropathy in mother. Empty and full squares with error bars represent retransformed means with their $95 \%$ confidence intervals for GDM - and GDM+ women, respectively. F is the F-statistics and $p$ is the $p$-value for the factor GDM.

\subsection{Alterations in Steroidome in the Maternal Blood Related to GDM}

A number of significant steroidomic changes were found in mothers with GDM $(\mathrm{GDM}+)$, indicating the primary role of the maternal compartment in GDM pathophysiology in terms of steroidomics. Out of the total 101 steroids in GDM+ mothers, six showed higher levels, 41 steroids had lower levels, two steroids showed insignificant factor GDM but significant interaction GDM $\times$ Stage (Table 1). Fifty-two steroids were unrelated to GDM (Table S1). The levels of all steroids under investigation in the maternal venous blood for GDM+ and GDM - women in three stages of the study (week 24-28 of gestation, week 30-36 of gestation, Labor) are shown in Tables 1 and S1.

\subsection{1. $\Delta^{5}$ Steroids}

From the $\Delta^{5}$ pregnane steroids ( 8 analytes), the levels of two of them (pregnenolone and $20 \alpha$-dihydropregnenolone sulfate) were higher in GDM+ women, the levels of $16 \alpha$ hydroxypregnenolone sulfate were lower in GDM+ women and the levels of five steroids 
pregnenolone sulfate, 17-hydroxypregnenolone, 17-hydroxypregnenolone sulfate, $16 \alpha$ hydroxypregnenolone, and 20 $\alpha$-dihydropregnenolone did not differ between the GDM+ and GDM - groups (Tables 1 and S1).

From the $\Delta^{5}$ androstane steroids (11 analytes), the levels of DHEA sulfate were higher in GDM+ women, the levels of five steroids ( $7 \alpha$ - and $7 \beta$-hydroxy-DHEA, 5 -androstene$3 \beta, 7 \alpha, 17 \beta$-triol, 5 -androstene- $3 \beta, 16 \alpha, 17 \beta$-triol and its sulfate) were lower in the GDM+ group, and the levels of five steroids (DHEA, 7-oxo-DHEA, androstenediol, androstenediol sulfate, and 5 -androstene- $3 \beta, 7 \beta, 17 \beta$-triol) did not significantly differ between the groups (Tables 1 and S1).

\subsection{2. $\Delta^{4}$ Steroids}

From the $\Delta^{4}$ pregnanes (seven analytes), the levels of two steroids (conjugated $17 \alpha, 20 \alpha$ dihydroxy-4-pregnen-3-one and 20 $\alpha$-dihydroprogesterone) were lower in the GDM+ group, while the differences in levels of five steroids (progesterone, 17-hydroxyprogesterone, $17 \alpha, 20 \alpha$-dihydroxy-4-pregnene-3-one, conjugated $20 \alpha$-dihydroprogesterone) did not reach statistical significance (Tables 1 and S1).

However, the significant GDM $\times$ Stage interactions for progesterone, 16 $\alpha$-hydroxyprog esterone and $20 \alpha$-dihydroprogesterone showed different relationships with gestational age (GA) for the GDM+ and GDM - groups in these steroids. While from week 24 to week 36 of gestation, the progesterone and 16 $\alpha$-hydroxyprogesterone levels were higher in the GDM+ group, the situation was different at labor. In progesterone levels, there was a fall between week 30-36 of gestation and labor for GDM+ group, while no such difference was found in GDM- group. The 16 $\alpha$-hydroxyprogesterone levels did not differ between week 30-36 of gestation and labor in the GDM+ group but continued to grow in the GDMgroup (Table 1).

The levels of $20 \alpha$-dihydroprogesterone gradually raised from week $24-28$ to labor, but this raise was slower in the GDM+ group, so the levels were markedly lower at labor when compared with the GDM- group (Table 1).

From the $\Delta^{4}$ androstanes (5 analytes), the levels of two steroids (testosterone and $16 \alpha$-hydroxytestosterone) were lower in the GDM+ group, while the levels of three steroids (androstenedione, conjugated testosterone, and conjugated epitestosterone) did not differ between the GDM+ and GDM - groups (Tables 1 and S1).

\subsubsection{Balance between 17-Hydroxy-Steroids and Corresponding 17-Deoxy-Steroids}

To estimate the influence of GDM and GA on activities of steroidogenic enzymes the appropriate product to precursor ratios (PPRs) were used.

Concerning the PPRs, the authors are aware that what happens in the blood (i.e., plasma levels) may not directly correlate with the function of the enzymes possibly related. Of course, the enzymes are present in different tissues that contribute in a different way to the plasma levels. However, numerous authors used the product-to-precursor ratios as surrogate markers for various diseases as well as for explanation of a variety of physiological and pathophysiological processes $[49,50]$.

The relationships between PPRs that may reflect the activities of CYP17A1 in the 17hydroxylase step and factors Group and Stage are shown in Table 2. From the 7 PPRs, those for the $\Delta^{5}$ pathway (17-hydroxy-pregnenolone/pregnenolone and 17-hydroxy-pregnenolone/ pregnenolone, sulfates) did not differ between the GDM+ and GDM- groups. The corresponding PPRs for the $\Delta^{4}$ pathway (17-hydroxy-progesterone/progesterone) showed lower values for the GDM+ group, as did the PPR for $5 \alpha / \beta$-reduced pregnanes, where the differences between the GDM+ and GDM- groups were even more pronounced (Table 2). 
Table 2. Profiles of product to precursor ratios that may reflect the balance between 17-hydroxy-steroids and corresponding 17-deoxy-steroids and possibly also the activity of CYP17A1 (17-hydroxylase step) in the GDM- and GDM+ groups from week 24 of gestation to labor.

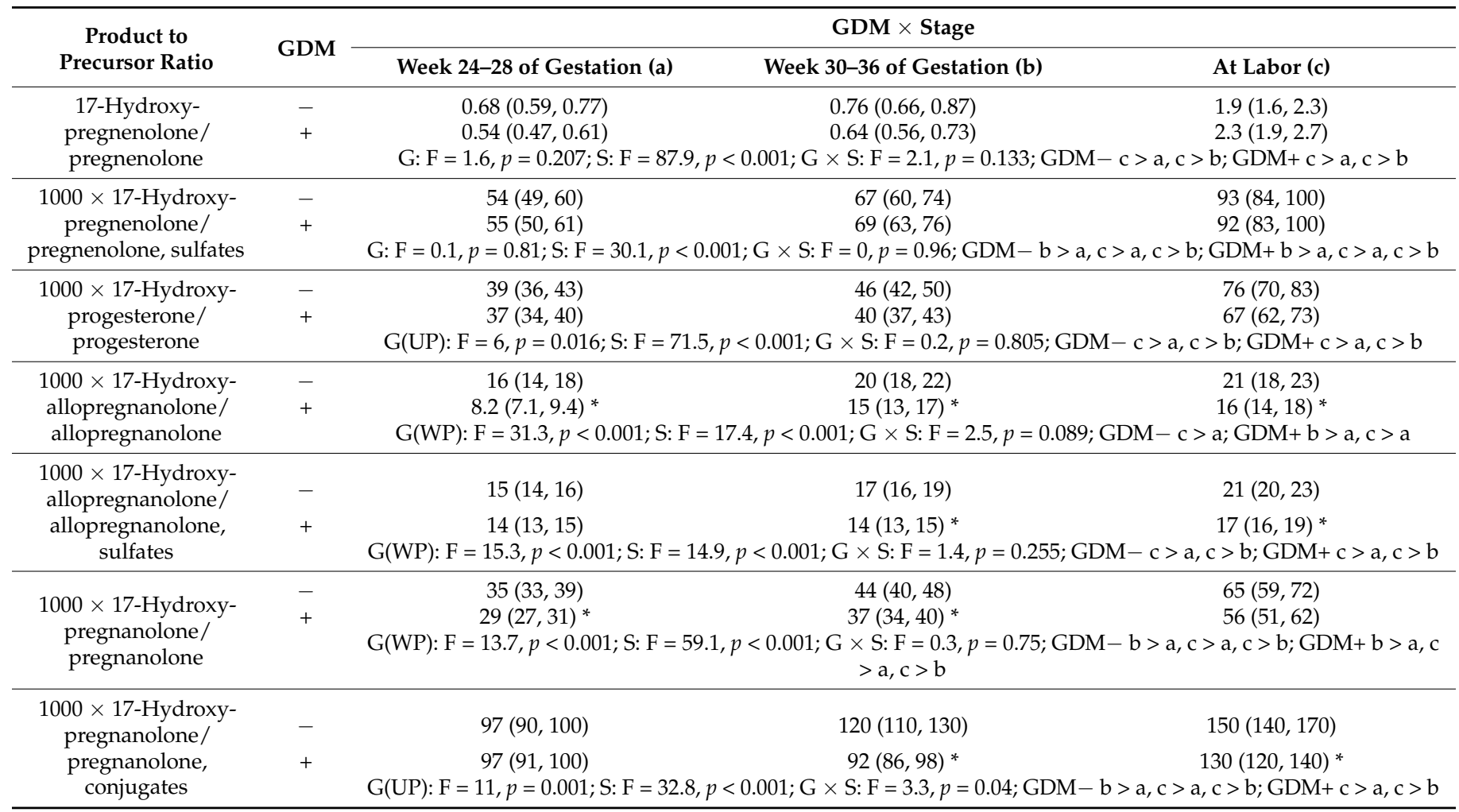

The symbols are the same as for Table 1 .

\subsubsection{Balance between Androstanes and Corresponding 17-Hydroxy-Steroids}

The relationships between PPRs that may reflect the activities of CYP17A1 in the C17,20-lyase step and GDM are shown in Table 3. DHEA/17-hydroxypregnenolone significantly differs at labor only, when the values for the GDM+ group were markedly lower in comparison with the GDM - group. The PPR for the sulfated steroids did not differ between the groups, and the same was valid for the androstenedione/17-hydroxyprogesterone ratio in the $\Delta^{4}$ pathway. On the other hand, the PPRs for the $5 \alpha / \beta$-reduced steroids were consistently higher in the GDM+ group (Table 3). The values of the DHEA/17hydroxypregnenolone ratio decreased more rapidly in the GDM+ group (Table 3).

\subsubsection{Estrogens}

Concerning the estrogens ( 6 analytes), four steroids (estrone sulfate, estradiol, estradiol sulfate, and estriol sulfate) were lower in the GDM+ group. The between-group differences in estrone and estriol did not reach significance (Tables 1 and S1). 
Table 3. Profiles of product to precursor ratios that may reflect balance between 17-hydroxy-steroids and corresponding C19-steroids and possibly also the activity of CYP17A1 (C17,20-lyase step) in the GDM- and GDM+ groups from week 24 of gestation to labor.

\begin{tabular}{|c|c|c|c|c|}
\hline \multirow{2}{*}{$\begin{array}{l}\text { Product to } \\
\text { Precursor Ratio }\end{array}$} & \multirow{2}{*}{ GDM } & \multicolumn{3}{|c|}{ GDM $\times$ Stage } \\
\hline & & Week 24-28 of Gestation (a) & Week 30-36 of Gestation (b) & Labor (c) \\
\hline \multirow{3}{*}{$\begin{array}{l}\text { DHEA/17-hydroxy- } \\
\text { pregnenolone }\end{array}$} & - & $1.1(0.99,1.1)$ & $0.97(0.91,1)$ & $0.9(0.84,0.97)$ \\
\hline & + & $1.1(1.1,1.2)$ & $0.88(0.82,0.94)$ & $0.65(0.6,0.7)$ * \\
\hline & & \multicolumn{3}{|c|}{ 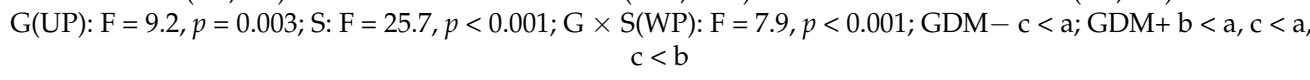 } \\
\hline \multirow{3}{*}{$\begin{array}{l}\text { DHEA/17-hydroxy- } \\
\text { pregnenolone, } \\
\text { sulfates }\end{array}$} & - & $130(120,150)$ & $88(76,100)$ & $45(39,52)$ \\
\hline & + & $150(130,170)$ & $88(77,100)$ & $49(42,56)$ \\
\hline & & \multicolumn{3}{|c|}{$\begin{array}{c}\mathrm{G}: \mathrm{F}=0.5, p=0.475 ; \mathrm{S}: \mathrm{F}=69.8, p<0.001 ; \mathrm{G} \times \mathrm{S}: \mathrm{F}=0.1, p=0.874 ; \mathrm{GDM}-\mathrm{b}<\mathrm{a}, \mathrm{c}<\mathrm{a}, \mathrm{c}<\mathrm{b} ; \mathrm{GDM}+\mathrm{b}<\mathrm{a}, \\
\mathrm{c}<\mathrm{a}, \mathrm{c}<\mathrm{b}\end{array}$} \\
\hline \multirow{3}{*}{$\begin{array}{l}1000 \times \\
\text { Androstenedione/17- } \\
\text { hydroxyprogesterone }\end{array}$} & - & $0.43(0.38,0.48)$ & $0.33(0.29,0.37)$ & $0.35(0.31,0.4)$ \\
\hline & + & $0.4(0.36,0.45)$ & $0.3(0.26,0.33)$ & $0.44(0.39,0.49)$ \\
\hline & & \multicolumn{3}{|c|}{$\mathrm{G}: \mathrm{F}=0.1, p=0.737 ; \mathrm{S}: \mathrm{F}=7.9, p<0.001 ; \mathrm{G} \times \mathrm{S}: \mathrm{F}=2.6, p=0.082 ; \mathrm{GDM}-\mathrm{b}<\mathrm{a} ; \mathrm{GDM}+\mathrm{b}<\mathrm{a}, \mathrm{c}>\mathrm{b}$} \\
\hline \multirow{3}{*}{$\begin{array}{l}1000 \times \text { Androsterone/17- } \\
\text { hydroxyallopregnanolone }\end{array}$} & - & $1.4(1.2,1.7)$ & $1.1(0.97,1.3)$ & $1.3(1.1,1.5)$ \\
\hline & + & $2.7(2.3,3.2) *$ & $1.4(1.2,1.6)$ & $1.4(1.2,1.6)$ \\
\hline & & \multicolumn{3}{|c|}{$\mathrm{G}(\mathrm{UP}): \mathrm{F}=12.3, p<0.001 ; \mathrm{S}: \mathrm{F}=11, p<0.001 ; \mathrm{G} \times \mathrm{S}: \mathrm{F}=2.8, p=0.069 ; \mathrm{GDM}-; \mathrm{GDM}+\mathrm{b}<\mathrm{a}, \mathrm{c}<\mathrm{a}$} \\
\hline \multirow{3}{*}{$\begin{array}{l}\text { Androsterone/17-hydroxy- } \\
\text { allopregnanolone, sulfates }\end{array}$} & - & $32(28,36)$ & $21(18,24)$ & $21(18,24)$ \\
\hline & + & $49(44,55)$ * & $28(25,31) *$ & $24(21,27)$ \\
\hline & & \multicolumn{3}{|c|}{$\mathrm{G}(\mathrm{WP}): \mathrm{F}=17.8, p<0.001 ; \mathrm{S}: \mathrm{F}=29.7, p<0.001 ; \mathrm{G} \times \mathrm{S}: \mathrm{F}=2, p=0.147 ; \mathrm{GDM}-\mathrm{b}<\mathrm{a}, \mathrm{c}<\mathrm{a} ; \mathrm{GDM}+\mathrm{b}<\mathrm{a}, \mathrm{c}<\mathrm{a}$} \\
\hline \multirow{3}{*}{$\begin{array}{l}1000 \times \text { Etiocholanolone/ } \\
\text { 17-hydroxypregnanolone }\end{array}$} & - & $0.28(0.25,0.32)$ & $0.21(0.19,0.23)$ & $0.23(0.21,0.26)$ \\
\hline & + & $0.34(0.3,0.38)$ & $0.23(0.21,0.25)$ & $0.26(0.24,0.29)$ \\
\hline & & \multicolumn{3}{|c|}{$\mathrm{G}(\mathrm{UP}): \mathrm{F}=4.5, p=0.037 ; \mathrm{S}: \mathrm{F}=12.3, p<0.001 ; \mathrm{G} \times \mathrm{S}: \mathrm{F}=0.2, p=0.809 ; \mathrm{GDM}-\mathrm{b}<\mathrm{a} ; \mathrm{GDM}+\mathrm{b}<\mathrm{a}, \mathrm{c}<\mathrm{a}$} \\
\hline $1000 \times$ Etiocholanolone/17- & - & $0.64(0.58,0.7)$ & $0.38(0.34,0.42)$ & $0.37(0.33,0.41)$ \\
\hline \multirow{2}{*}{$\begin{array}{l}\text { hydroxypregnanolone, } \\
\text { conjugates }\end{array}$} & + & $0.82(0.75,0.9) *$ & $0.46(0.42,0.51)$ & $0.45(0.4,0.49)$ \\
\hline & & \multicolumn{3}{|c|}{$\mathrm{G}(\mathrm{WP}): \mathrm{F}=14.7, p<0.001 ; \mathrm{S}: \mathrm{F}=47, p<0.001 ; \mathrm{G} \times \mathrm{S}: \mathrm{F}=0.3, p=0.78 ; \mathrm{GDM}-\mathrm{b}<\mathrm{a}, \mathrm{c}<\mathrm{a} ; \mathrm{GDM}+\mathrm{b}<\mathrm{a}, \mathrm{c}<\mathrm{a}$} \\
\hline
\end{tabular}

The symbols are the same as for Table 1 .

\subsection{6. $5 \alpha$-Reduced Steroids and Steroid $5 \alpha$-Reductases (SRD5As)}

From the $5 \alpha$-reduced-steroids ( 31 analytes), the levels of 18 steroids (allopregnanolone sulfate, isopregnanolone sulfate, conjugated $5 \alpha$-pregnane- $3 \alpha, 20 \alpha$-diol, conjugated $5 \alpha$ pregnane-3 $\beta, 20 \alpha$-diol, 17-hydroxyallopregnanolone, 17-hydroxyallopregnanolone sulfate, $5 \alpha$-pregnane- $3 \alpha, 17 \alpha, 20 \alpha$-triol, $5 \alpha$-pregnane-3 $3,17 \alpha, 20 \alpha$-triol, and conjugated $5 \alpha$-pregnane$3 \beta, 17 \alpha, 20 \alpha$-triol, androsterone, epiandrosterone sulfate, $5 \alpha$-androstane- $3 \alpha, 17 \beta$-diol, conjugated $5 \alpha$-androstane- $3 \alpha, 17 \beta$-diol, $5 \alpha$-androstane- $3 \beta, 17 \beta$-diol, conjugated $5 \alpha$-androstane$3 \beta, 17 \beta$-diol, 11 $\beta$-hydroxyandrosterone, 11 $\beta$-hydroxyandrosterone sulfate, and $11 \beta$ hydroxyepiandrosterone) were lower in the GDM+ group. $3 \alpha, 5 \alpha$-Tetrahydrocorticosterone levels were higher in the GDM+ group. The levels of 12 steroids ( $5 \alpha$-dihydroprogesterone, allopregnanolone, isopregnanolone, $5 \alpha, 20 \alpha$-tetrahydroprogesterone, conjugated $5 \alpha, 20 \alpha$ tetrahydroprogesterone, $5 \alpha$-pregnane- $3 \alpha, 20 \alpha$-diol, $5 \alpha$-pregnane- $3 \beta, 20 \alpha$-diol, and conjugated $5 \alpha$-pregnane- $3 \alpha, 17 \alpha, 20 \alpha$-triol, $5 \alpha$-androstane-3,17-dione, androsterone sulfate, epiandrosterone, and $11 \beta$-hydroxyepiandrosterone sulfate) did not significantly differ between the groups (Tables 1 and S1).

The seven PPRs that may reflect the $5 \alpha$-reductase (SRD5As) activities are presented in Table 4. 
Table 4. Profiles of product to precursor ratios that may reflect the SRD5As activities in the GDM- and GDM+ groups from week 24 of gestation to labor.

\begin{tabular}{|c|c|c|c|c|}
\hline \multirow{2}{*}{ Product to Precursor Ratio } & \multirow{2}{*}{ GDM } & \multicolumn{3}{|c|}{ GDM $\times$ Stage } \\
\hline & & Week 24-28 of Gestation (a) & Week 30-36 of Gestation (b) & Labor (c) \\
\hline \multirow{3}{*}{$\begin{array}{l}1000 \times(5 \alpha \text {-Dihydroprogesterone } \\
+ \text { allopregnanolone }+ \\
\text { isopregnanolone }) / \text { progesterone }\end{array}$} & - & $0.25(0.23,0.27)$ & $0.24(0.22,0.26)$ & $0.3(0.27,0.33)$ \\
\hline & + & $0.21(0.2,0.23)$ & $0.21(0.19,0.23)$ & $0.3(0.27,0.33)$ \\
\hline & & \multicolumn{3}{|c|}{$\mathrm{G}: \mathrm{F}=3.6, p=0.06 ; \mathrm{S}: \mathrm{F}=14.7, p<0.001 ; \mathrm{G} \times \mathrm{S}: \mathrm{F}=1.1, p=0.335 ; \mathrm{GDM}-\mathrm{c}>\mathrm{b} ; \mathrm{GDM}+\mathrm{c}>\mathrm{a}, \mathrm{c}>\mathrm{b}$} \\
\hline \multirow{3}{*}{$\begin{array}{c}(5 \alpha, 20 \alpha \text {-Tetrahydroprogesterone }+ \\
5 \alpha / \beta \text {-Pregnane- } 3 \beta, 20 \alpha \text { - } \\
\text { diols }) / 20 \alpha \text {-dihydroprogesterone }\end{array}$} & - & $1.5(1.4,1.6)$ & $1.3(1.2,1.4)$ & $1.5(1.4,1.5)$ \\
\hline & + & $1.2(1.1,1.3)$ * & $1.2(1.2,1.3)$ & $1.4(1.3,1.5)$ \\
\hline & & \multicolumn{3}{|c|}{$\mathrm{G}(\mathrm{UP}): \mathrm{F}=8.9, p=0.004 ; \mathrm{S}: \mathrm{F}=4.7, p=0.012 ; \mathrm{G} \times \mathrm{S}: \mathrm{F}=2.5, p=0.087 ; \mathrm{GDM}-\mathrm{b}<\mathrm{a} ; \mathrm{GDM}+\mathrm{c}>\mathrm{a}, \mathrm{c}>\mathrm{b}$} \\
\hline \multirow{3}{*}{$\begin{array}{l}1000 \times 17- \\
\text { Hydroxyallopregnanolone/17- } \\
\text { hydroxyprogesterone }\end{array}$} & - & $25(22,30)$ & $23(20,26)$ & $20(17,23)$ \\
\hline & + & $12(9.8,14) *$ & $18(15,21)$ & $18(15,21)$ \\
\hline & & \multicolumn{3}{|c|}{$\mathrm{G}(\mathrm{WP}): \mathrm{F}=17.5, p<0.001 ; \mathrm{S}: \mathrm{F}=1.1, p=0.323 ; \mathrm{G} \times \mathrm{S}(\mathrm{WP}): \mathrm{F}=5.9, p=0.004 ; \mathrm{GDM}+\mathrm{b}>\mathrm{a}, \mathrm{c}>\mathrm{a}$} \\
\hline \multirow{3}{*}{$\begin{array}{l}1000 \times 5 \alpha \text {-Pregnane- } 3 \alpha / \beta, 17 \\
20 \alpha \text {-triols } / 17,20 \alpha \text {-dihydroxy-4- } \\
\text { pregnene-3-one }\end{array}$} & \multirow{3}{*}{-} & $68(61,76)$ & $44(40,49)$ & $35(32,39)$ \\
\hline & & $55(50,61) *$ & $40(36,44)$ & $35(32,39)$ \\
\hline & & $\mathrm{G}: \mathrm{F}=3.5, p=0.066 ; \mathrm{S}: \mathrm{F}=$ & $\begin{array}{c}p<0.001 ; \mathrm{G} \times \mathrm{S}: \mathrm{F}=1.2, p=\mathrm{c} \\
\mathrm{GDM}+\mathrm{b}<\mathrm{a}, \mathrm{c}<\mathrm{a}\end{array}$ & $-\mathrm{b}<\mathrm{a}, \mathrm{c}<\mathrm{a}, \mathrm{c}<\mathrm{b}$ \\
\hline \multirow{3}{*}{$\begin{array}{l}\text { (5 } \alpha \text {-Androstane-3,17-dione + } \\
\text { androsterone + epiandros- } \\
\text { terone)/androstenedione }\end{array}$} & \multirow{3}{*}{+} & $0.22(0.2,0.23)$ & $0.18(0.17,0.19)$ & $0.19(0.18,0.2)$ \\
\hline & & $0.2(0.18,0.21)$ & $0.17(0.16,0.18)$ & $0.17(0.16,0.18)$ \\
\hline & & $\mathrm{G}: \mathrm{F}=3.9, p=0.051 ; \mathrm{S}: \mathrm{F}=$ & $\rho=0.001 ; \mathrm{G} \times \mathrm{S}: \mathrm{F}=0.5, p=0.6$ & $-\mathrm{b}<\mathrm{a} ; \mathrm{GDM}+\mathrm{c}<\mathrm{a}$ \\
\hline \multirow{3}{*}{ 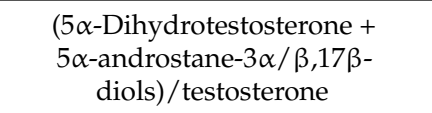 } & \multirow{3}{*}{+} & $0.29(0.25,0.33)$ & $0.24(0.21,0.27)$ & $0.18(0.16,0.21)$ \\
\hline & & $0.26(0.22,0.3)$ & $0.21(0.18,0.25)$ & $0.18(0.16,0.21)$ \\
\hline & & $\mathrm{G}: \mathrm{F}=1, p=0.325 ; \mathrm{S}: \mathrm{F}=8$ & $<0.001 ; \mathrm{G} \times \mathrm{S}: \mathrm{F}=0.2, p=0.8$ & $\mathrm{c}<\mathrm{a} ; \mathrm{GDM}+\mathrm{c}<\mathrm{a}$ \\
\hline \multirow{3}{*}{$\begin{array}{c}1000 \times \\
(11 \beta-\text {-Hydroxyandrosterone }+11 \beta- \\
\text { hydroxyepiandrosterone }) / 11 \beta- \\
\text { hydroxyandrostenedione }\end{array}$} & - & $7.3(6.5,8.3)$ & $7.1(6.3,8.1)$ & $11(9.8,12)$ \\
\hline & \multirow[t]{2}{*}{+} & $4.3(3.8,4.8)$ * & $4.3(3.8,4.8)$ * & $6.1(5.4,6.8)$ * \\
\hline & & \multicolumn{3}{|c|}{$\begin{array}{c}\mathrm{G}(\mathrm{WP}): \mathrm{F}=64, p<0.001 ; \mathrm{S}: \mathrm{F}=16.7, p<0.001 ; \mathrm{G} \times \mathrm{S}: \mathrm{F}=0.2, p=0.828 ; \mathrm{GDM}-\mathrm{c}>\mathrm{a}, \mathrm{c}>\mathrm{b} \\
\mathrm{GDM}+\mathrm{c}>\mathrm{a}, \mathrm{c}>\mathrm{b}\end{array}$} \\
\hline
\end{tabular}

The symbols are the same as for Table 1 .

\subsection{7. $5 \beta$-Reduced Steroids and Steroid $5 \beta$-Reductase (AKR1D1)}

The relationships between $5 \beta$-reduced steroids and GDM were inconsistent (Tables 1 and S1) and none of the PPRs that may reflect AKR1D1 were significantly associated with GDM (Table S3).

\subsubsection{The Balance between $17 \beta$-hydroxy- and 17-oxo-steroids}

From the nine ratios that may reflect the balance between $17 \beta$-hydroxy- and 17-oxosteroids (Table 5), three ratios showed lower values in the GDM+ group than in the GDMgroup (androstenediol/DHEA, testosterone/androstenedione, estradiol/estrone), four ratios did not differ between the groups ( $5 \alpha$-dihydrotestosterone $/ 5 \alpha$-androstane-3,17-dione, $5 \alpha$-androstane- $3 \alpha, 17 \beta$-diol/androsterone, $5 \alpha$-androstane- $3 \beta, 17 \beta$-diol/epiandrosterone, $11 \beta$-hydroxy-testosterone $/ 11 \beta$-hydroxyandrostenedione), and two ratios showed higher values in the GDM+ group (5-androstene- $3 \beta, 7 \alpha, 17 \beta$-triol/ $7 \alpha$-hydroxy-DHEA, 5 -androstene$3 \beta, 7 \beta, 17 \beta$-triol $/ 7 \beta$-hydroxy-DHEA) (Table 5). 
Table 5. Profiles of product to precursor ratios that may reflect the balance between $17 \beta$-hydroxy-and 17-oxo-steroids in the GDM- and GDM+ groups from week 24 of gestation to labor.

\begin{tabular}{|c|c|c|c|c|}
\hline \multirow{2}{*}{ Product to Precursor Ratios } & \multirow{2}{*}{ GDM } & \multicolumn{3}{|c|}{ GDM $\times$ Stage } \\
\hline & & Week 24-28 of Gestation (a) & Week 30-36 of Gestation (b) & Labor (c) \\
\hline \multirow{3}{*}{ Androstenediol/DHEA } & - & $0.21(0.2,0.23)$ & $0.19(0.18,0.21)$ & $0.2(0.18,0.21)$ \\
\hline & + & $0.19(0.18,0.2)$ & $0.19(0.18,0.2)$ & $0.16(0.15,0.17) *$ \\
\hline & & \multicolumn{3}{|c|}{$\mathrm{G}(\mathrm{UP}): \mathrm{F}=7.5, p=0.007 ; \mathrm{S}: \mathrm{F}=3.5, p=0.035 ; \mathrm{G} \times \mathrm{S}: \mathrm{F}=1.9, p=0.154 ; \mathrm{GDM}+\mathrm{c}<\mathrm{a}, \mathrm{c}<\mathrm{b}$} \\
\hline \multirow{3}{*}{$\begin{array}{l}\text { 5-Androstene- } 3 \beta, 7 \alpha, 17 \beta \text { - } \\
\text { triol } / 7 \alpha \text {-hydroxy-DHEA }\end{array}$} & - & $0.4(0.35,0.46)$ & $0.31(0.28,0.36)$ & $0.33(0.29,0.38)$ \\
\hline & + & $0.56(0.49,0.66) *$ & $0.42(0.37,0.48) *$ & $0.33(0.29,0.38)$ \\
\hline & & \multicolumn{3}{|c|}{$\mathrm{G}(\mathrm{UP}): \mathrm{F}=7.7, p=0.007 ; \mathrm{S}: \mathrm{F}=7.7, p<0.001 ; \mathrm{G} \times \mathrm{S}: \mathrm{F}=2.1, p=0.128 ; \mathrm{GDM}+\mathrm{b}<\mathrm{a}, \mathrm{c}<\mathrm{a}$} \\
\hline \multirow{3}{*}{$\begin{array}{l}\text { 5-Androstene- } 3 \beta, 7 \beta, 17 \beta \text { - } \\
\text { triol/7 } / \text {-hydroxy-DHEA }\end{array}$} & - & $0.1(0.087,0.12)$ & $0.14(0.12,0.16)$ & $0.25(0.21,0.29)$ \\
\hline & + & $0.16(0.14,0.19) *$ & $0.22(0.19,0.26)^{*}$ & $0.31(0.26,0.36)$ \\
\hline & & \multicolumn{3}{|c|}{$\mathrm{G}(\mathrm{WP}): \mathrm{F}=16.3, p<0.001 ; \mathrm{S}: \mathrm{F}=23.6, p<0.001 ; \mathrm{G} \times \mathrm{S}: \mathrm{F}=0.7, p=0.502 ; \mathrm{GDM}-\mathrm{c}>\mathrm{a}, \mathrm{c}>\mathrm{b} ; \mathrm{GDM}+\mathrm{c}>\mathrm{a}, \mathrm{c}>\mathrm{b}$} \\
\hline \multirow{3}{*}{ Testosterone/androstenedione } & - & $0.43(0.4,0.46)$ & $0.37(0.34,0.4)$ & $0.38(0.36,0.41)$ \\
\hline & + & $0.35(0.32,0.37)^{*}$ & $0.35(0.32,0.38)$ & $0.32(0.3,0.35)^{*}$ \\
\hline & & \multicolumn{3}{|c|}{$\mathrm{G}(\mathrm{UP}): \mathrm{F}=11.9, p<0.001 ; \mathrm{S}: \mathrm{F}=1.9, p=0.161 ; \mathrm{G} \times \mathrm{S}: \mathrm{F}=1.5, p=0.239 ; \mathrm{GDM}-\mathrm{b}<\mathrm{a}$} \\
\hline \multirow{3}{*}{ Estradiol/estrone } & - & $3.9(3.4,4.6)$ & $4.3(3.7,5)$ & $2.5(2.1,2.8)$ \\
\hline & + & $3.4(2.9,3.9)$ & $3.8(3.3,4.4)$ & $1.9(1.7,2.2)$ \\
\hline & & \multicolumn{3}{|c|}{$\mathrm{G}(\mathrm{UP}): \mathrm{F}=4.8, p=0.031 ; \mathrm{S}: \mathrm{F}=22.7, p<0.001 ; \mathrm{G} \times \mathrm{S}: \mathrm{F}=0.2, p=0.805 ; \mathrm{GDM}-\mathrm{c}<\mathrm{a}, \mathrm{c}<\mathrm{b} ; \mathrm{GDM}+\mathrm{c}<\mathrm{a}, \mathrm{c}<\mathrm{b}$} \\
\hline \multirow{3}{*}{$\begin{array}{l}5 \alpha \text {-Dihydrotestosterone } / 5 \alpha \text { - } \\
\text { androstane-3,17-dione }\end{array}$} & - & $0.77(0.68,0.86)$ & $0.71(0.62,0.8)$ & $0.47(0.41,0.54)$ \\
\hline & + & $0.74(0.64,0.85)$ & $0.62(0.53,0.71)$ & $0.59(0.5,0.69)$ \\
\hline & & \multicolumn{3}{|c|}{$\mathrm{G}: \mathrm{F}=0, p=0.898 ; \mathrm{S}: \mathrm{F}=7, p=0.002 ; \mathrm{G} \times \mathrm{S}: \mathrm{F}=1.7, p=0.192 ; \mathrm{GDM}-\mathrm{c}<\mathrm{a}, \mathrm{c}<\mathrm{b}$} \\
\hline \multirow{3}{*}{$\begin{array}{l}5 \alpha \text {-Androstane- } 3 \alpha, 17 \beta- \\
\text { diol/androsterone }\end{array}$} & - & $0.25(0.23,0.28)$ & $0.26(0.23,0.28)$ & $0.22(0.2,0.24)$ \\
\hline & + & $0.27(0.25,0.3)$ & $0.25(0.22,0.27)$ & $0.21(0.19,0.23)$ \\
\hline & & \multicolumn{3}{|c|}{$\mathrm{G}: \mathrm{F}=0, p=0.995 ; \mathrm{S}: \mathrm{F}=5.7, p=0.005 ; \mathrm{G} \times \mathrm{S}: \mathrm{F}=0.6, p=0.558 ; \mathrm{GDM}+\mathrm{c}<\mathrm{a}$} \\
\hline \multirow{3}{*}{$\begin{array}{l}5 \alpha \text {-Androstane- } 3 \beta, 17 \beta- \\
\text { diol/epiandrosterone }\end{array}$} & - & $0.5(0.4,0.62)$ & $0.51(0.42,0.64)$ & $0.23(0.18,0.29)$ \\
\hline & + & $0.59(0.48,0.73)$ & $0.47(0.37,0.58)$ & $0.28(0.22,0.35)$ \\
\hline & & \multicolumn{3}{|c|}{$\mathrm{G}: \mathrm{F}=0.5, p=0.494 ; \mathrm{S}: \mathrm{F}=15.6, p<0.001 ; \mathrm{G} \times \mathrm{S}: \mathrm{F}=0.6, p=0.553 ; \mathrm{GDM}-\mathrm{c}<\mathrm{a}, \mathrm{c}<\mathrm{b} ; \mathrm{GDM}+\mathrm{c}<\mathrm{a}, \mathrm{c}<\mathrm{b}$} \\
\hline \multirow{3}{*}{$\begin{array}{c}1000 \times 11 \beta \text {-Hydroxy- } \\
\text { testosterone } / 11 \beta- \\
\text { hydroxyandrostenedione }\end{array}$} & - & $71(49,100)$ & $100(74,140)$ & $110(78,150)$ \\
\hline & + & $61(38,91)$ & $100(70,140)$ & $62(39,93)$ \\
\hline & & \multicolumn{3}{|c|}{$\mathrm{G}: \mathrm{F}=1.3, p=0.255 ; \mathrm{S}: \mathrm{F}=1.6, p=0.214 ; \mathrm{G} \times \mathrm{S}: \mathrm{F}=0.7, p=0.521$} \\
\hline
\end{tabular}

The symbols are the same as for Table 1 .

\subsection{9. $16 \alpha$-Hydroxylation}

Concerning the steroid $16 \alpha$-hydroxylation, the differences between the GDM+ and GDM- groups were not consistent (Table S4).

\subsubsection{The Balance between Conjugated and Unconjugated Steroids}

To assess the effect of GDM and GA on the balance between conjugated and unconjugated steroids the ratios of steroid conjugates to unconjugated steroids (C/F) were evaluated. No consistent trend was observed concerning the relations between $\mathrm{C} / \mathrm{Fs}$ and GDM status. However, despite the relatively low overall consistency, the results were more consistent for GABAergic steroids showing lower C/F in GDM+ women (allopregnanolone, pregnanolone, androsterone, $5 \alpha$-androstane- $3 \alpha, 17 \beta$-diol) (Table 6).

\subsubsection{3 $\beta$-Hydroxysteroid Dehydrogenases (HSD3Bs)}

From the seven PPRs that may reflect the activities of HSD3Bs, two of them (progesterone/pregnenolone, $16 \alpha$-hydroxytestosterone /5-androstene- $3 \beta, 16 \alpha, 17 \beta$-triol) showed lower values in the GDM+ group, 4 PPRs did not significantly differ between the groups (20 $\alpha$-dihydroprogesterone / $20 \alpha$-dihydropregnenolone, 17-hydroxyprogesterone/17hydroxypregnenolone, androstenedione/DHEA, testosterone/androstenediol) and 16 $\alpha-$ hydroxyprogesterone/16 $\alpha$-hydroxy-pregnenolone values were higher in the GDM+ group (Table 7). 
Table 6. Profiles of sulfated to unsulfated steroid ratios in the GDM- and GDM+ groups from week 24 of gestation to labor.

\begin{tabular}{|c|c|c|c|c|}
\hline \multirow{2}{*}{ Steroid } & \multirow{2}{*}{ GDM } & \multicolumn{3}{|c|}{ GDM $\times$ Stage } \\
\hline & & Week 24-28 of Gestation (a) & Week 30-36 of Gestation (b) & Labor (c) \\
\hline \multirow{3}{*}{ Pregnenolone } & - & $39(35,43)$ & $37(34,41)$ & $82(72,94)$ \\
\hline & + & $26(23,28)$ * & $28(26,31) *$ & $78(69,89)$ \\
\hline & & \multicolumn{3}{|c|}{$\begin{array}{c}\mathrm{G}(\mathrm{WP}): \mathrm{F}=20.8, p<0.001 ; \mathrm{S}: \mathrm{F}=106.1, p<0.001 ; \mathrm{G} \times \mathrm{S}(\mathrm{WP}): \mathrm{F}=4.3, p=0.017 ; \mathrm{GDM}-\mathrm{c}>\mathrm{a}, \mathrm{c}>\mathrm{b} \\
\mathrm{GDM}+\mathrm{c}>\mathrm{a}, \mathrm{c}>\mathrm{b}\end{array}$} \\
\hline \multirow{3}{*}{$20 \alpha$-Dihydropregnenolone } & - & $230(210,250)$ & $230(210,250)$ & $170(160,190)$ \\
\hline & + & $210(190,230)$ & $240(220,260)$ & $220(200,240) *$ \\
\hline & & \multicolumn{3}{|c|}{$\mathrm{G}: \mathrm{F}=1.3, p=0.267 ; \mathrm{S}: \mathrm{F}=5.9, p=0.004 ; \mathrm{G} \times \mathrm{S}(\mathrm{WP}): \mathrm{F}=3.7, p=0.028 ; \mathrm{GDM}-\mathrm{c}<\mathrm{a}, \mathrm{c}<\mathrm{b}$} \\
\hline \multirow{3}{*}{ 17-Hydroxypregnenolone } & - & $3(2.7,3.3)$ & $3.2(2.9,3.5)$ & $3(2.7,3.3)$ \\
\hline & + & $2.6(2.4,2.9)$ & $2.9(2.6,3.1)$ & $3.2(2.9,3.5)$ \\
\hline & & \multicolumn{3}{|c|}{$\mathrm{G}: \mathrm{F}=1, p=0.316 ; \mathrm{S}: \mathrm{F}=1, p=0.366 ; \mathrm{G} \times \mathrm{S}: \mathrm{F}=1.2, p=0.31$} \\
\hline \multirow{3}{*}{ 16 $\alpha$-Hydroxypregnenolone } & - & $74(57,97)$ & $80(61,100)$ & $79(61,100)$ \\
\hline & + & $55(42,72)$ & $49(37,65)$ & $72(55,95)$ \\
\hline & & \multicolumn{3}{|c|}{$\mathrm{G}: \mathrm{F}=3.6, p=0.06 ; \mathrm{S}: \mathrm{F}=0.6, p=0.528 ; \mathrm{G} \times \mathrm{S}: \mathrm{F}=0.6, p=0.568$} \\
\hline \multirow{3}{*}{ DHEA } & - & $350(320,390)$ & $270(240,300)$ & $170(150,190)$ \\
\hline & + & $320(290,360)$ & $290(260,320)$ & $180(160,200)$ \\
\hline & & \multicolumn{3}{|c|}{$\mathrm{G}: \mathrm{F}=0, p=0.837 ; \mathrm{S}: \mathrm{F}=39.4, p<0.001 ; \mathrm{G} \times \mathrm{S}: \mathrm{F}=0.7, p=0.507 ; \mathrm{GDM}-\mathrm{b}<\mathrm{a}, \mathrm{c}<\mathrm{a}, \mathrm{c}<\mathrm{b} ; \mathrm{GDM}+\mathrm{c}<\mathrm{a}, \mathrm{c}<\mathrm{b}$} \\
\hline \multirow{3}{*}{ Androstenediol } & - & $140(120,170)$ & $170(140,200)$ & $140(120,170)$ \\
\hline & + & $150(130,180)$ & $180(160,220)$ & $230(190,270) *$ \\
\hline & & \multicolumn{3}{|c|}{$\mathrm{G}(\mathrm{UP}): \mathrm{F}=4.5, p=0.037 ; \mathrm{S}: \mathrm{F}=2.2, p=0.115 ; \mathrm{G} \times \mathrm{S}: \mathrm{F}=2.2, p=0.12 ; \mathrm{GDM}+\mathrm{c}>\mathrm{a}$} \\
\hline \multirow{3}{*}{$\begin{array}{l}\text { 5-Androstene- } 3 \beta, 16 \alpha, \\
\quad 17 \beta \text {-triol }\end{array}$} & - & $160(140,180)$ & $170(150,190)$ & $160(150,180)$ \\
\hline & + & $140(120,160)$ & $150(130,170)$ & $190(170,220)$ \\
\hline & & \multicolumn{3}{|c|}{$\mathrm{G}: \mathrm{F}=0.3, p=0.575 ; \mathrm{S}: \mathrm{F}=2.4, p=0.1 ; \mathrm{G} \times \mathrm{S}: \mathrm{F}=2.4, p=0.094 ; \mathrm{GDM}+\mathrm{c}>\mathrm{a}, \mathrm{c}>\mathrm{b}$} \\
\hline \multirow{3}{*}{ Estrone } & - & $5.9(4.4,8.1)$ & $7.1(5.2,9.7)$ & $7.5(5.6,10)$ \\
\hline & + & $4.9(3.6,6.5)$ & $5.4(4.1,7.3)$ & $5.2(3.9,7)$ \\
\hline & & \multicolumn{3}{|c|}{$\mathrm{G}: \mathrm{F}=2.7, p=0.106 ; \mathrm{S}: \mathrm{F}=0.4, p=0.697 ; \mathrm{G} \times \mathrm{S}: \mathrm{F}=0.1, p=0.918$} \\
\hline \multirow{3}{*}{ Estradiol } & - & $0.54(0.43,0.67)$ & $0.59(0.47,0.74)$ & $0.75(0.61,0.94)$ \\
\hline & + & $0.5(0.4,0.62)$ & $0.53(0.43,0.66)$ & $0.61(0.49,0.76)$ \\
\hline & & $\mathrm{G}: \mathrm{F}=1.1, p$ & $293 ; \mathrm{S}: \mathrm{F}=1.7, p=0.186 ; \mathrm{G} \times \mathrm{S}:$ & 0.885 \\
\hline & - & $4.5(3.6,5.6)$ & $4.9(3.9,6)$ & $7.1(5.8,8.8)$ \\
\hline Estriol & + & $3.8(3.1,4.6)$ & $3.3(2.7,4)$ & $6.5(5.3,8.1)$ \\
\hline & & $\mathrm{G}: \mathrm{F}=3.4, p=0.068 ; \mathrm{S}: \mathrm{F}=8$ & $0.001 ; \mathrm{G} \times \mathrm{S}: \mathrm{F}=0.6, p=0.533$ & $\mathrm{a} ; \mathrm{GDM}+\mathrm{c}>\mathrm{a}, \mathrm{c}>\mathrm{b}$ \\
\hline & - & $39(36,42)$ & $42(38,45)$ & $45(41,49)$ \\
\hline Allopregnanolone & + & $26(24,29) *$ & $36(33,39)$ & $45(42,49)$ \\
\hline & & $\mathrm{G}(\mathrm{WP}): \mathrm{F}=13.6, p<0.001 ; \mathrm{S}: \mathrm{F}$ & $9, p<0.001 ; \mathrm{G} \times \mathrm{S}(\mathrm{WP}): \mathrm{F}=6.2$ & $\mathrm{GDM}+\mathrm{b}>\mathrm{a}, \mathrm{c}>\mathrm{a}, \mathrm{c}>\mathrm{b}$ \\
\hline & - & $68(63,74)$ & $74(68,81)$ & $110(99,120)$ \\
\hline Isopreonanolone & + & $50(46,54) *$ & $63(59,69)$ & $120(110,130)$ \\
\hline isopregnanoione & & $\mathrm{G}(\mathrm{UP}): \mathrm{F}=6.3, p=0.014 ; \mathrm{S}:$ & $\begin{array}{l}7.9, p<0.001 ; \mathrm{G} \times \mathrm{S}(\mathrm{WP}): \mathrm{F}=8 \\
\mathrm{GDM}+\mathrm{b}>\mathrm{a}, \mathrm{c}>\mathrm{a}, \mathrm{c}>\mathrm{b}\end{array}$ & GDM-c $>a, c>b$ \\
\hline & - & $41(36,47)$ & $45(39,52)$ & $54(47,63)$ \\
\hline Hydroxvallonreonanolone & + & $51(44,59)$ & $37(33,43)$ & $56(48,66)$ \\
\hline Hydroxyallopregnanolone & & $\mathrm{G}: \mathrm{F}=0.1, p=0.801$ & $=4.9, p=0.009 ; \mathrm{G} \times \mathrm{S}: \mathrm{F}=2.2, p$ & $a+b<a, c>b$ \\
\hline & - & $930(850,1000)$ & $780(710,850)$ & $800(730,870)$ \\
\hline Androsterone & + & $970(890,1100)$ & $890(810,970)$ & $970(890,1100) *$ \\
\hline & & $\mathrm{G}(\mathrm{UP}): \mathrm{F}=6.3, p=0$ & $\mathrm{~F}=2.6, p=0.077 ; \mathrm{G} \times \mathrm{S}: \mathrm{F}=0$ & GDM $-\mathrm{b}<\mathrm{a}$ \\
\hline & - & $590(520,680)$ & $730(630,840)$ & $370(320,420)$ \\
\hline Epiandrosterone & + & $460(400,530)$ & $470(410,530) *$ & $290(250,340)$ \\
\hline & & $\mathrm{G}(\mathrm{WP}): \mathrm{F}=16.2, p<0.001 ; \mathrm{S}: \mathrm{F}=2$ & $<0.001 ; \mathrm{G} \times \mathrm{S}: \mathrm{F}=0.8, p=0.476$ & $\mathrm{a}, \mathrm{c}<\mathrm{b} ; \mathrm{GDM}+\mathrm{c}<\mathrm{a}, \mathrm{c}<\mathrm{b}$ \\
\hline & - & $21(19,25)$ & $28(25,33)$ & $17(15,20)$ \\
\hline $11 \beta$-Hydroxyandrosterone & + & $22(20,26)$ & $33(29,38)$ & $22(19,25)$ \\
\hline & & $\mathrm{G}: \mathrm{F}=3.3, p=0.072 ; \mathrm{S}: \mathrm{F}=13.2$ & $001 ; \mathrm{G} \times \mathrm{S}: \mathrm{F}=0.5, p=0.614 ; \mathrm{G}$ & $c<b ; G D M+b>a, c<b$ \\
\hline & - & $280(210,380)$ & $340(250,460)$ & $160(120,210)$ \\
\hline Hydroxyepiandrosterone & + & $450(330,630)$ & $480(350,650)$ & $210(160,270)$ \\
\hline Hydroxyepiandrosterone & & $\mathrm{G}(\mathrm{UP}): \mathrm{F}=4.4, p=0.038 ; \mathrm{S}: \mathrm{F}=9$ & $0.001 ; \mathrm{G} \times \mathrm{S}: \mathrm{F}=0.1, p=0.881$ & $\mathrm{a}, \mathrm{c}<\mathrm{b} ; \mathrm{GDM}+\mathrm{c}<\mathrm{a}, \mathrm{c}<\mathrm{b}$ \\
\hline
\end{tabular}


Table 7. Profiles of product to precursor ratios that may reflect HSD3Bs activities in the GDM- and GDM+groups from week 24 of gestation to labor.

\begin{tabular}{|c|c|c|c|c|}
\hline \multirow{2}{*}{ Product to Precursor Ratios } & \multirow{2}{*}{ GDM } & \multicolumn{3}{|c|}{ GDM $\times$ Stage } \\
\hline & & Week 24-28 of Gestation (a) & Week 30-36 of Gestation (b) & At Labor (c) \\
\hline \multirow{3}{*}{ Progesterone/pregnenolone } & - & $70(62,78)$ & $90(80,100)$ & $91(80,100)$ \\
\hline & + & $62(55,70)$ & $80(71,90)$ & $65(58,73)$ * \\
\hline & & \multicolumn{3}{|c|}{$\mathrm{G}(\mathrm{UP}): \mathrm{F}=7.7, p=0.006 ; \mathrm{S}: \mathrm{F}=5.1, p=0.008 ; \mathrm{G} \times \mathrm{S}: \mathrm{F}=1.1, p=0.333 ; \mathrm{GDM}-\mathrm{b}>\mathrm{a}, \mathrm{c}>\mathrm{a} ; \mathrm{GDM}+\mathrm{b}>\mathrm{a}$} \\
\hline \multirow{3}{*}{$\begin{array}{l}20 \alpha- \\
\text { Dihydroprogesterone } / 20 \alpha- \\
\text { dihydropregnenolone }\end{array}$} & - & $36(33,40)$ & $63(58,69)$ & $45(41,49)$ \\
\hline & + & $38(36,42)$ & $58(54,62)$ & $43(40,47)$ \\
\hline & & \multicolumn{3}{|c|}{$\mathrm{G}: \mathrm{F}=0.3, p=0.599 ; \mathrm{S}: \mathrm{F}=44.8, p<0.001 ; \mathrm{G} \times \mathrm{S}: \mathrm{F}=1.1, p=0.35 ; \mathrm{GDM}-\mathrm{b}>\mathrm{a}, \mathrm{c}>\mathrm{a}, \mathrm{c}<\mathrm{b} ; \mathrm{GDM}+\mathrm{b}>\mathrm{a}, \mathrm{c}<\mathrm{b}$} \\
\hline \multirow{3}{*}{$\begin{array}{l}17- \\
\text { Hydroxyprogesterone/17- } \\
\text { hydroxypregnenolone }\end{array}$} & - & $4.1(3.5,4.8)$ & $5.6(4.8,6.5)$ & $2.8(2.3,3.4)$ \\
\hline & + & $4.5(3.8,5.2)$ & $5.3(4.5,6.1)$ & $2.1(1.7,2.5)$ \\
\hline & & \multicolumn{3}{|c|}{$\mathrm{G}: \mathrm{F}=0.8, p=0.374 ; \mathrm{S}: \mathrm{F}=24.3, p<0.001 ; \mathrm{G} \times \mathrm{S}: \mathrm{F}=1.2, p=0.314 ; \mathrm{GDM}-\mathrm{c}<\mathrm{a}, \mathrm{c}<\mathrm{b} ; \mathrm{GDM}+\mathrm{c}<\mathrm{a}, \mathrm{c}<\mathrm{b}$} \\
\hline \multirow{3}{*}{$\begin{array}{l}16 \alpha- \\
\text { Hydroxyprogesterone/16 } \alpha- \\
\text { hydroxypregnenolone }\end{array}$} & - & $19(17,21)$ & $22(20,25)$ & $18(16,20)$ \\
\hline & + & $23(21,25)$ & $25(23,28)$ & $18(16,20)$ \\
\hline & & \multicolumn{3}{|c|}{$\mathrm{G}(\mathrm{UP}): \mathrm{F}=4.4, p=0.038 ; \mathrm{S}: \mathrm{F}=7.5, p<0.001 ; \mathrm{G} \times \mathrm{S}: \mathrm{F}=0.8, p=0.477 ; \mathrm{GDM}-\mathrm{c}<\mathrm{b} ; \mathrm{GDM}+\mathrm{c}<\mathrm{a}, \mathrm{c}<\mathrm{b}$} \\
\hline \multirow{3}{*}{ Androstenedione/DHEA } & - & $1.5(1.4,1.7)$ & $1.7(1.5,1.8)$ & $1.1(1,1.2)$ \\
\hline & + & $1.5(1.3,1.6)$ & $1.7(1.5,1.8)$ & $0.99(0.91,1.1)$ \\
\hline & & \multicolumn{3}{|c|}{$\mathrm{G}: \mathrm{F}=1.3, p=0.257 ; \mathrm{S}: \mathrm{F}=32.4, p<0.001 ; \mathrm{G} \times \mathrm{S}: \mathrm{F}=0.7, p=0.519 ; \mathrm{GDM}-\mathrm{c}<\mathrm{a}, \mathrm{c}<\mathrm{b} ; \mathrm{GDM}+\mathrm{c}<\mathrm{a}, \mathrm{c}<\mathrm{b}$} \\
\hline \multirow{3}{*}{ Testosterone/androstenediol } & - & $3(2.8,3.3)$ & $3.2(2.9,3.5)$ & $2.2(2.1,2.5)$ \\
\hline & + & $2.8(2.6,3.1)$ & $3.1(2.8,3.4)$ & $1.9(1.7,2) *$ \\
\hline & & \multicolumn{3}{|c|}{$\mathrm{G}: \mathrm{F}=3.6, p=0.062 ; \mathrm{S}: \mathrm{F}=27.7, p<0.001 ; \mathrm{G} \times \mathrm{S}: \mathrm{F}=1, p=0.385 ; \mathrm{GDM}-\mathrm{c}<\mathrm{a}, \mathrm{c}<\mathrm{b} ; \mathrm{GDM}+\mathrm{c}<\mathrm{a}, \mathrm{c}<\mathrm{b}$} \\
\hline \multirow{3}{*}{$\begin{array}{l}16 \alpha \text {-Hydroxytestosterone } / 5- \\
\text { androstene- } 3 \beta, 16 \alpha, 17 \beta \text {-triol }\end{array}$} & - & $7.4(6.3,8.7)$ & $9.8(8.4,11)$ & $5.4(4.5,6.5)$ \\
\hline & + & $6.1(5.1,7.2)$ & $7.1(6,8.2)^{*}$ & $4.8(3.9,5.7)$ \\
\hline & & \multicolumn{3}{|c|}{$\mathrm{G}(\mathrm{UP}): \mathrm{F}=5.5, p=0.021 ; \mathrm{S}: \mathrm{F}=9.2, p<0.001 ; \mathrm{G} \times \mathrm{S}: \mathrm{F}=0.6, p=0.58 ; \mathrm{GDM}-\mathrm{c}<\mathrm{b} ; \mathrm{GDM}+\mathrm{c}<\mathrm{b}$} \\
\hline
\end{tabular}

The symbols are the same as for Table 1 .

3.2.12. Conversion of Adrenal Androgens to Their $7 \alpha / \beta$-Hydroxy-Derivatives

From the four PPRs that may reflect the conversion of adrenal androgens to their $7 \alpha / \beta$-hydroxy-derivatives, the ratios of $7 \alpha$-hydroxy-DHEA/DHEA and $7 \beta$-hydroxyDHEA/DHEA showed lower values in the GDM+ group when compared with the GDMgroup. No significant between-group differences were found in 5 -androstene-3 $3,7 \alpha, 17 \beta$ triol/androstenediol and androstene- $3 \beta, 7 \alpha, 17 \beta$-triol/androstenediol ratios (Table 8 ).

Table 8. Profiles of product to precursor ratios that may reflect the conversion of adrenal androgens to their $7 \alpha / \beta$-hydroxyderivatives in the GDM - and GDM+ groups from week 24 of gestation to labor.

\begin{tabular}{|c|c|c|c|c|}
\hline \multirow{2}{*}{ Product to Precursor Ratios } & \multirow{2}{*}{ GDM } & \multicolumn{3}{|c|}{ GDM $\times$ Stage } \\
\hline & & Week 24-28 of Gestation (a) & Week 30-36 of Gestation (b) & At Labor (c) \\
\hline \multirow{3}{*}{$\begin{array}{c}1000 \times \\
7 \alpha \text {-Hydroxy-DHEA/DHEA }\end{array}$} & - & $82(75,91)$ & $86(78,94)$ & $94(86,100)$ \\
\hline & + & $62(56,69) *$ & $84(77,92)$ & $78(71,86) *$ \\
\hline & & \multicolumn{3}{|c|}{$\mathrm{G}(\mathrm{UP}): \mathrm{F}=9.1, p=0.003 ; \mathrm{S}: \mathrm{F}=4.6, p=0.012 ; \mathrm{G} \times \mathrm{S}: \mathrm{F}=1.9, p=0.153 ; \mathrm{GDM}+\mathrm{b}>\mathrm{a}, \mathrm{c}>\mathrm{a}$} \\
\hline \multirow{3}{*}{$\begin{array}{l}1000 \times \\
\text { 5-Androstene-3 } \beta, 7 \alpha, 17 \beta- \\
\text { triol/androstenediol }\end{array}$} & - & $150(140,170)$ & $150(140,170)$ & $170(160,190)$ \\
\hline & + & $190(170,210)$ & $190(170,210)$ & $150(140,170)$ \\
\hline & & \multicolumn{3}{|c|}{$\mathrm{G}: \mathrm{F}=2.5, p=0.114 ; \mathrm{S}: \mathrm{F}=0.2, p=0.798 ; \mathrm{G} \times \mathrm{S}: \mathrm{F}=3.6, p=0.031 ; \mathrm{GDM}+\mathrm{c}<\mathrm{a}$} \\
\hline \multirow{3}{*}{$\begin{array}{c}1000 \times \\
7 \beta-\text { Hydroxy-DHEA/DHEA }\end{array}$} & - & $86(74,98)$ & $81(70,93)$ & $58(49,68)$ \\
\hline & + & $53(44,62) *$ & $71(61,81)$ & $48(41,57)$ \\
\hline & & \multicolumn{3}{|c|}{$\mathrm{G}(\mathrm{UP}): \mathrm{F}=9.5, p=0.003 ; \mathrm{S}: \mathrm{F}=6.1, p=0.003 ; \mathrm{G} \times \mathrm{S}: \mathrm{F}=1.7, p=0.183 ; \mathrm{GDM}-\mathrm{c}<\mathrm{a}, \mathrm{c}<\mathrm{b} ; \mathrm{GDM}+\mathrm{c}<\mathrm{b}$} \\
\hline \multirow{3}{*}{$\begin{array}{l}1000 \times \\
\text { 5-Androstene-3 } \beta, 7 \alpha, 17 \beta- \\
\text { triol/androstenediol }\end{array}$} & - & $44(36,53)$ & $60(50,72)$ & $85(72,100)$ \\
\hline & + & $51(42,62)$ & $69(58,82)$ & $75(63,88)$ \\
\hline & & \multicolumn{3}{|c|}{$\mathrm{G}: \mathrm{F}=0.2, p=0.629 ; \mathrm{S}: \mathrm{F}=9.5, p<0.001 ; \mathrm{G} \times \mathrm{S}: \mathrm{F}=0.9, p=0.412 ; \mathrm{GDM}-\mathrm{c}>\mathrm{a}, \mathrm{c}>\mathrm{b} ; \mathrm{GDM}+\mathrm{c}>\mathrm{a}$} \\
\hline
\end{tabular}

The symbols are the same as for Table 1 .

\subsubsection{Type $111 \beta$-Hydroxysteroid Dehydrogenase (HSD11B1)}

From the five PPRs that may reflect the HSD11B1 activity, the 7 $\beta$-hydroxy-DHEA/7oxo-DHEA ratio was significantly lower in the GDM+ group, 3 PPRs (7-oxo-DHEA/ $7 \alpha-$ hydroxy-DHEA, 5-androstene-3 $\beta, 7 \beta, 17 \beta$-triol/5-androstene-3 $\beta, 7 \alpha, 17 \beta$-triol, $7 \beta$-hydroxyDHEA $/ 7 \alpha$-hydroxy-DHEA) did not differ between the groups. The cortisol/cortisone 
ratio showed higher values in the GDM+ group when compared with the GDM- group (Table 9).

Table 9. Profiles of product to precursor ratios that may reflect HSD11B1 activity in the GDM- and GDM+ groups from week 24 of gestation to labor.

\begin{tabular}{|c|c|c|c|c|}
\hline \multirow{2}{*}{ Product to Precursor Ratios } & \multirow{2}{*}{ GDM } & \multicolumn{3}{|c|}{ GDM $\times$ Stage } \\
\hline & & Week 24-28 of Gestation (a) & Week 30-36 of Gestation (b) & At Labor (c) \\
\hline \multirow{3}{*}{$\begin{array}{c}\text { 7-oxo-DHEA } / 7 \alpha \text {-hydroxy- } \\
\text { DHEA }\end{array}$} & - & $1.3(1.1,1.5)$ & $2(1.6,2.3)$ & $1.1(0.94,1.4)$ \\
\hline & + & $1.6(1.4,2)$ & $1.9(1.6,2.2)$ & $1.1(0.94,1.4)$ \\
\hline & & \multicolumn{3}{|c|}{$\mathrm{G}: \mathrm{F}=0.5, p=0.488 ; \mathrm{S}: \mathrm{F}=9, p<0.001 ; \mathrm{G} \times \mathrm{S}: \mathrm{F}=0.8, p=0.459 ; \mathrm{GDM}-\mathrm{b}>\mathrm{a}, \mathrm{c}<\mathrm{b} ; \mathrm{GDM}+\mathrm{c}<\mathrm{b}$} \\
\hline \multirow{3}{*}{$\begin{array}{l}\text { 5-Androstene- } 3 \beta, 7 \beta, 17 \beta \text { - } \\
\text { triol } / 5 \text {-androstene- } \\
3 \beta, 7 \alpha, 17 \beta \text {-triol }\end{array}$} & - & $0.27(0.23,0.32)$ & $0.34(0.29,0.39)$ & $0.44(0.38,0.51)$ \\
\hline & + & $0.29(0.25,0.34)$ & $0.36(0.31,0.42)$ & $0.46(0.4,0.53)$ \\
\hline & & \multicolumn{3}{|c|}{$\mathrm{G}: \mathrm{F}=0.6, p=0.428 ; \mathrm{S}: \mathrm{F}=10.6, p<0.001 ; \mathrm{G} \times \mathrm{S}: \mathrm{F}=0, p=0.975 ; \mathrm{GDM}-\mathrm{c}>\mathrm{a} ; \mathrm{GDM}+\mathrm{c}>\mathrm{a}$} \\
\hline \multirow{3}{*}{$\begin{array}{c}\text { 7ß-Hydroxy-DHEA/7-oxo- } \\
\text { DHEA }\end{array}$} & - & $0.97(0.82,1.1)$ & $0.61(0.52,0.71)$ & $0.54(0.46,0.64)$ \\
\hline & + & $0.5(0.43,0.59)$ * & $0.42(0.36,0.48)$ * & $0.5(0.43,0.58)$ \\
\hline & & \multicolumn{3}{|c|}{$\mathrm{G}(\mathrm{WP}): \mathrm{F}=17, p<0.001 ; \mathrm{S}: \mathrm{F}=5.7, p=0.005 ; \mathrm{G} \times \mathrm{S}: \mathrm{F}=3.5, p=0.035 ; \mathrm{GDM}-\mathrm{b}<\mathrm{a}, \mathrm{c}<\mathrm{a}$} \\
\hline \multirow{3}{*}{$\begin{array}{l}\text { 7ß-Hydroxy-DHEA/ } 7 \alpha- \\
\text { hydroxy-DHEA }\end{array}$} & - & $1(0.91,1.1)$ & $0.9(0.79,1)$ & $0.6(0.51,0.7)$ \\
\hline & + & $0.8(0.69,0.91)$ & $0.82(0.71,0.92)$ & $0.65(0.56,0.74)$ \\
\hline & & \multicolumn{3}{|c|}{$\mathrm{G}: \mathrm{F}=2, p=0.166 ; \mathrm{S}: \mathrm{F}=9.4, p<0.001 ; \mathrm{G} \times \mathrm{S}: \mathrm{F}=1.7, p=0.195 ; \mathrm{GDM}-\mathrm{c}<\mathrm{a}, \mathrm{c}<\mathrm{b}$} \\
\hline \multirow{3}{*}{ Cortisol/cortisone } & - & $4.2(3.9,4.5)$ & $3.5(3.3,3.8)$ & $4.8(4.4,5.1)$ \\
\hline & + & $4.5(4.2,4.9)$ & $4.1(3.9,4.4)$ * & $6(5.5,6.5) *$ \\
\hline & & \multicolumn{3}{|c|}{$\mathrm{G}(\mathrm{WP}): \mathrm{F}=14.1, p<0.001 ; \mathrm{S}: \mathrm{F}=22.6, p<0.001 ; \mathrm{G} \times \mathrm{S}: \mathrm{F}=0.9, p=0.414 ; \mathrm{GDM}-\mathrm{b}<\mathrm{a}, \mathrm{c}>\mathrm{b} ; \mathrm{GDM}+\mathrm{c}>\mathrm{a}, \mathrm{c}>\mathrm{b}$} \\
\hline
\end{tabular}

The symbols are the same as for Table 1 .

\section{Discussion}

\subsection{Comparison of Alterations in Maternal and Fetal Steroidome Related to GDM}

The data indicates that the effect of GDM on the fetal steroidome (Figure 1, Table S2) is considerably weaker compared to maternal steroidogenesis (Tables 1 and S1). Since in the cord blood there were three $5 \alpha / \beta$-reduced metabolites of 17-hydroxyprogesterone and one $5 \alpha$-reduced androgen, which showed lower levels in the GDM+ group, it can be concluded that GDM may be associated with lower activity of CYP17A1 in the C17-hydroxylase step at least (Figure 1, Table S2). Whereas the placenta has low activity of CYP17A1, it cannot substantially affect the percentage of $5 \alpha / \beta$-reduced 17-deoxy-, 17-hydroxy-pregnanes and $5 \alpha / \beta$-reduced androstanes during transplacental passage from mother into the fetus. However, it readily metabolizes $\Delta^{5}$ and $\Delta^{4}$ steroids. Since none of the $\Delta^{5}$ or $\Delta^{4}$ steroids in cord blood showed significant differences between the GDM+ and GDM- groups (Table S2), the differences in the $5 \alpha / \beta$-reduced metabolites of 17 -hydroxyprogesterone and one $5 \alpha$-reduced androgen may be considered as a sign of reduced activity of maternal and/or placental CYP17A1 in GDM+ group (see [51]).

\subsection{Alterations in Maternal Steroidome Related to GDM}

\subsubsection{Higher Levels of Pregnenolone in Late Gestation in the GDM+ Group}

Interestingly, in the group of steroids that were consistently higher in the circulation of GDM+ women in all stages of the study, there was pregnenolone whose levels did not differ in cord blood between the GDM+ and GDM- groups (Tables 1 and S2). Unlike pregnenolone, the levels of PregS, 17-hydroxypregnenolone and its sulfate did not differ between the GDM+ and GDM - groups (Tables 1 and S1). This could be explained by the increased CYP11A1 activity at reduced activity of both CYP17A1 and SULT2A1 in mothers with GDM. However, the 17-hydroxypregnenolone to pregnenolone ratio did not differ between the GDM+ and GDM - groups (Table 2). The lower ratio of sulfated to unsulfated pregnenolone between week 24-28 and week 30-36 of gestation (Table 6) was consistent with reduced SULT2A1 activity in GDM+ women in adrenal zona fasciculata (ZF) where the PregS is primarily produced.

It is known that both PregS and DHEAS act on various ionotropic receptors, which differently influence the glucose homeostasis. Because PregS levels did not differ between 
the GDM+ and GDM - groups, while DHEAS levels were slightly but significantly higher in women with GDM+, a slightly diabetogenic effect of sulfated $\Delta^{5}$ steroids can be assumed in late gestation.

4.2.2. The Increase of Diabetogenic Effects with Advancing GA Is Associated with Mounting Progesterone Levels

Progesterone in pregnancy is of placental origin and is synthesized partly from the maternal LDL and partly from the fetal PregS, and then secreted to both maternal and fetal circulation [52,53]. Concerning the extremely elevated levels of progesterone in pregnant women and so much more in the fetus (Table 1), it is evident that even maternal progesterone levels are more dependent on fetal and placental steroidogenesis than on maternal production.

As already mentioned, progesterone is a central regulator of $\beta$-cell proliferation in response to metabolic challenges. Therefore progesterone increase between week 24-28 and week 30-36 of gestation may play a role in the suppression of IS and down-regulation of $\beta$-cell function in the later stages of gestation [12,27]). In addition, progesterone suppresses the IS in the $\beta$-cells via inhibition of TRPM3 channels [15]. Even if the effects of progesterone on IS may not be unidirectional [16,17], our data support the concept that the intensification of diabetogenic effects with advancing GA is associated with mounting progesterone levels and the predominant progesterone effect appears to be diabetogenic, as the progesterone levels are consistently higher in the GDM+ group in week 24-28 and week 30-36 of gestation when compared with the GDM- group. However, the situation is reversed at labor. A trend towards lower levels of $16 \alpha$-hydroxyprogesterone and $20 \alpha-$ dihydroprogesterone was also observed in the GDM+ group at labor (Table 1). In addition to its diabetogenic effects, progesterone as cortisol triggers immunoregulatory signals in $\mathrm{T}$ cells (see [51]).

4.2.3. Lower Testosterone Levels in the GDM+ Group Are Associated with Lower AKR1C3 Activity

Similar dependence on GA, like the $\Delta^{5}$ steroids, was exhibited also in the $\Delta^{4}$ androstanes (Tables 1 and S1). These steroids are primarily synthesized in the sequence DHEA, androstenedione (catalyzed by HSD3B2), testosterone (catalyzed by HSD17B3 and AKR1C3) or in the sequence DHEA, androstenediol (catalyzed by AKR1C3, and HSD17B3), testosterone (catalyzed by HSD3B2) [49,50]. The levels of testosterone were consistently lower in the GDM+ group in contrast to the levels of androstenedione and androstenediol (Tables 1 and S1). The androstenedione/DHEA ratio and testosterone/androstenediol ratio did not differ between the groups (Table 5) but the testosterone/androstenedione and androstenediol/DHEA ratios were lower in the GDM+ group (Table 5). Since the HSD17B3 is a testicular enzyme, while the AKR1C3 is widely expressed in various tissues and explicitly in adipocytes (and further tissues such as the digestive tract, smooth muscle, pancreas and to a much lesser extent also in adrenal zona reticularis (ZR)), the aforementioned data point to the reduced AKR1C3 activity in the GDM+ group. Since the aforementioned tissues play an important role in the pathophysiology of DM2, these findings may be relevant for GDM pathophysiology.

\subsubsection{Lower Levels of Estrogens and GDM Pathophysiology}

From the total number of six estrogens, the levels of four of them, including the bioactive estradiol, were lower in the GDM+ group (Tables 1 and S1).

Concerning the PPRs that may reflect the activity of aromatase (CYP19A1), neither the estrone/androstenedione ratio nor the estradiol/testosterone ratio [49,50] differed significantly between the GDM+ and GDM - groups (Table S5). Instead, the estradiol/estrone ratio that may reflect the balance between placental enzymes such as reductive HSD17B1 and oxidative HSD17B2 [49,50] showed lower values in the GDM+ group (Table 5). Hence, this shift may be responsible for the relative estradiol deficit in the GDM+ group. Estradiol is an important antidiabetic steroid operating via binding to nuclear receptors as well as 
via modulation of ion channels controlling the secretion of pancreatic hormones [12,27-32]. Therefore, the estradiol deficiency in the GDM+ group may be an important component participating in the pathophysiology of GDM.

4.2.5. Lower Activity of CYP17A1 in the Hydroxylase Step at Higher Activity in the Lyase Step in GDM+ Women

While the PPRs that may reflect the CYP17A1 activity in the hydroxylase step for $\Delta^{5}$ pregnanes did not significantly differ between the GDM+ and GDM - groups, they were significantly lower for $\Delta^{4}$ pregnanes and $5 \alpha / \beta$-reduced pregnanes (Table 2). Alternatively, the PPRs that may reflect the CYP17A1 activity for the $5 \alpha / \beta$-reduced steroids in the lyase step were markedly higher, particularly in week $24-28$ of gestation (Table 3 ). These data outline the importance of the "backdoor pathway" in the metabolism of pregnane steroids, as the $5 \alpha$-reduced- (and possibly $5 \beta$-reduced), $3 \alpha$-hydroxy-pregnanes are excellent substrates with high affinity for CYP17A1 (in both hydroxylase and lyase steps) [54]. Moreover, these more stable reduced catabolites appear to be better indicators of the CYP17A1 activities than the $\Delta^{4}$ and $\Delta^{5}$ steroids. The functional activity of the "backdoor pathway" in placenta was recently hypothesized by Karahoda et al. [51].

4.2.6. Lower Conjugation of Some Neuroactive Pregnanolone Isomers and Pregnenolone in GDM+ Women

Conjugation of pregnane steroids may occur mainly via sulfation or glucuronidation pathways, and the proportions between the resulting conjugates may differ from steroid to steroid from almost $100 \%$ to about $50 \%$ of sulfates and/or disulfates [40,41,45,46].

In terms of the biological effects of neuroactive steroids, the activity of the steroidogenic enzymes responsible for steroid conjugation has a major influence. For instance, the sulfation of allopregnanolone blocks its neuroinhibitory effect on $\mathrm{GABA}_{\mathrm{A}} \mathrm{R}$ [55], glycine receptors (GlyR) [56], and $\alpha$-amino-3-hydroxy-5-methyl-4-isoxazolepropionic acid receptors (AMPAR) [19], and forms a slightly excitatory substance via positive modulation of N-methyl-D-aspartate receptors (NMDAR) [57]. On the other hand, the sulfation of allopregnanolone stops its excitatory effect in fetal rat hypothalamic neurons via L-type voltage-gated calcium channels (VGCC) [58]. Besides, the sulfation of pregnanolone reverses its neuroinhibitory activity on $\mathrm{GABA}_{A} R[23,59]$ but forms another neuroinhibitory agent, pregnanolone sulfate, negatively modulating NMDAR [60,61] and AMPAR [18]. In addition, the pregnanolone sulfate also inhibits the permeability of short transient receptor potential channel 5 (TRPC5) [62], influencing the fear-related behavior [63]. The sulfation of the steroid isopregnanolone amplifies its slight neuroexcitatory effect (via negative modulation of $\left.\mathrm{GABA}_{\mathrm{A}} \mathrm{R}\right)[64,65]$.

Despite the low uniformity in the balance between free and conjugated steroids, the results are more consistent in some groups of steroids, such as pregnanolone isomers (Table 6). Concerning the lower conjugation of these steroids in GDM+ women (pregnenolone, allopregnanolone, isopregnanolone, pregnanolone, androsterone, epiandrosterone, and $5 \alpha$-androstane- $3 \alpha, 17 \beta$-diol), the data indicate a prevalent trend to lower clearance for neuroinhibitory (neuroprotective) positive modulators of GABA $\mathrm{R}$ and GlyR (allopregnanolone, pregnanolone, androsterone, $5 \alpha$-androstane- $3 \alpha, 17 \beta$-diol) on one hand, but reduced formation of efficient excitatory sulfated steroids (pregnenolone sulfate, isopregnanolone sulfate) in GDM+ compared to the GDM- group $[23,55,56,59,64-68]$ on the other.

\subsubsection{Lowered $5 \alpha$-Reductase Activities in GDM+ Women}

SRD5As activities represent the rate-limiting step in the synthesis of neurosteroids and generally in the steroid catabolism [69,70]. The most PPRs that may reflect the SRD5As activities indicate lower values in GDM+ women than in controls (Table 4). The isoforms of SRD5As are expressed in numerous tissues including placenta [71,72]. Relative to tissue weight, the human placenta expresses SRD5A1 around 1000 times more than the testis (see [51]). The highest extraplacental expression of the SRD5A1 isoform has been reported 
in the fetal brain [72], which is likely related to increased fetal brain demands for synthesis of the neuroprotective GABAergic steroid allopregnanolone [70]. The SRD5A2 isoform is most expressed in the maternal liver [72].

Concerning the relationships between gestational diabetes and SRD5As, the data in the literature is scarce. Manjunath-Gowda reported results indicating reduced SRD5As activity in GDM+ women compared to controls [73]. Regarding the associations between SRD5As and DM2, Traish et al. found that the suppression of SRD5As activities by finasteride and dutasteride weaken the clearance of glucocorticoids (potentiating IR, diabetes and vascular disease) [69]. Other authors published that a dual inhibition of SRD5As, but not inhibition of SRD5A2 alone, modulates insulin sensitivity in human peripheral tissues rather than liver [74]. Nasiri et al. reported that SRD5A2 overexpression reduced the effects of cortisol to suppress lipogenesis, but SRD5A2 inhibition increased cortisol action [75]. Our data indicating reduced SRD5As activities in the GDM+ group are consistent with the above reports, and imply that reduced SRD5As activities may contribute to the pathophysiology of both DM2 and GDM.

4.2.8. Reduced 7-Hydroxylation of DHEA and Attenuated Competition of 7-Oxygenated Androstanes with Cortisone for HSD11B1 May Participate in the Pathophysiology of GDM

Endogenous 7-hydroxy- $\Delta^{5}$-steroids and their synthetic analogues are potential agents to treat autoimmune diseases [37]. From the immunoprotective and anti-inflammatory $\Delta^{5}$ $7 \alpha / \beta$-androstane steroids [76], the levels of $7 \alpha$-hydroxy-DHEA, $7 \beta$-hydroxy-DHEA, and 5 -androstene- $3 \beta, 7 \alpha, 17 \beta$-triol were significantly lower in the GDM+ group (Table 1). As regards the PPRs that may reflect the activities of $7 \alpha / \beta$-hydroxylating enzymes [36,77], those for DHEA were significantly lower in the GDM+ group (Table 8). It should be pointed out that the interconversion in the sequence $7 \alpha$-hydroxy-DHEA, 7 -oxo-DHEA, $7 \beta$-hydroxy-DHEA is catalyzed by the same enzyme (HSD11B1), which converts the inactive cortisone to the bioactive glucocorticoid cortisol [36]. From the PPRs that may reflect the HSD11B1 activity, the cortisol/cortisone ratio was higher in the GDM+ group when compared with the GDM - group, but another PPRs that may reflect the HSD11B1 activity $7 \beta$-Hydroxy-DHEA/7-oxo-DHEA was lower in the GDM+ group (Table 9). While cortisol levels did not differ between the groups, cortisone levels were lower in the GDM+ group (Tables 1 and S1). Taken together, this data could be explained as follows. The lower activity of the CYP7B1 enzyme results in reduced production of 7-oxygenated steroids, which may lead to decreased competition of these substances for active sites of the enzyme HSD11B1 with cortisone. As a result, the balance between cortisone and cortisol is shifted towards the active glucocorticoid cortisol. Since the bioactive cortisol, in contrast to inactive cortisone, belongs to diabetogenic steroids, the suggested mechanism may participate in GDM pathophysiology [78].

\section{Conclusions}

The present data show that GDM-related steroidomic changes are evident in the maternal blood, but not in the mixed umbilical blood. This suggests a decisive role for the maternal compartment in GDM pathophysiology, although concentrations of neuroactive steroids that can affect glucose homeostasis are generally significantly higher in mixed cord blood compared to maternal blood.

Concerning the levels of sulfated $\Delta^{5}$ steroids influencing the pathophysiology of GDM, our data indicates either a balanced or slightly pro-diabetogenic effect of these neuroactive substances.

In line with reports from other authors, our results demonstrate that the increase of diabetogenic effects is associated with mounting progesterone levels with the approaching term.

The GDM+ group exhibits lower testosterone levels, most probably due to attenuated AKR1C3 activity. Lower levels of antidiabetic estradiol in the GDM+ group may be associated with a shift from the reductive HSD17B1 activity to the activity of oxidative HSD17B2 isoform. The data also indicate that the suppressed production of antidiabetic estradiol may be an important component in the pathophysiology of GDM. 
The activity of CYP17A1 is an essential step of cortisol biosynthesis. Therefore, the observed trend to lower activity of CYP17A1 in the hydroxylase step in the GDM+ group may indicate some disruption in cortisol production.

The mostly decreasing activity in the CYP17A1 lyase step in GDM+ group women may be associated with increasing levels of estradiol towards term as estradiol suppresses the synthesis of adrenal androgens in the maternal compartment. The data regarding the CYP17A1 activity outline the importance of the "backdoor pathway" in the metabolism of C21 steroids, as the reduced pregnanes are excellent substrates with a high affinity to this enzyme [54]. These metabolically stable analytes appear to be better indicators of the CYP17A1 activity in both hydroxylase- and lyase steps than the $\Delta^{5}$ and $\Delta^{4}$ steroids.

The lower conjugation of some physiologically active steroids in GDM+ women indicates a prevalent trend to lower clearance for neuroinhibitory (and mostly neuroprotective) positive modulators of $\mathrm{GABA}_{\mathrm{A}} \mathrm{R}$ and lower formation of excitatory (and sometimes excitotoxic) sulfated steroids as pregnenolone sulfate and isopregnanolone sulfate in the GDM+ group. Moreover, the rising conjugation of neuroinhibitory GABAergic pregnanes and pregnancy-stabilizing steroids $5 \beta$-reduced pregnanes towards labor may also be connected with functional progesterone withdrawal.

Women with GDM showed reduced SRD5As activities, which may play a role in the pathophysiology of GDM in addition to DM2. However, in contrast to the diabetogenic effect of SRD5As, their overexpression might contribute to higher production of GABAergic (and neuroprotective) $5 \alpha$-reduced steroids.

The lower activity of the CYP7B1 enzyme results in reduced production of 7-oxygenated adrenal androgens, which may lead to decreased competition of these substances for active sites of the enzyme HSD11B1 with cortisone. As a result, the balance between cortisone and cortisol is shifted towards the active glucocorticoid cortisol. Since the bioactive cortisol in contrast to inactive cortisone belongs to diabetogenic steroids, the suggested mechanism may participate in GDM pathophysiology. The absent difference between the GDM+ and GDM- groups in cortisol levels may be explained with the suppressed CYP17A1-lyase activity in the GDM+ group and reduced of CYP7B1 activity in this group. Regarding the dependence on GA, the production of the immunoprotective 7-deoxy- and the more active 7-oxygenated adrenal androgens mounts towards labor, which may stimulate immunoprotective effects with the approaching term.

In conclusion, this study produces evidence that the maternal but not the fetal steroidome is substantially altered in women with GDM, which may have a number of consequences concerning the GDM pathophysiology.

Supplementary Materials: The following are available online at https:/ /www.mdpi.com/article/10 .3390 /biom11121746/s1, Table S1: Profiles of steroids in the GDM - and GDM+ groups from week 24 of gestation to labor unrelated to GDM, Table S2: Levels of steroids in mixed umbilical cord blood of GDM - and GDM+ women at labor, Table S3: Profiles of product to precursor ratios that may reflect the AKR1D1 activity in the GDM - and GDM+ groups from week 24 of gestation to labor, Table S4: Profiles of product to precursor ratios that may reflect the activity of $16 \alpha$-hydroxylating enzymes in the GDM - and GDM+ groups from week 24 of gestation to labor, Table S5: Profiles of product to precursor ratios that may reflect the activity of CYP19A1 (aromatase) in the GDM- and GDM+ groups from week 24 of gestation to labor.

Author Contributions: Conceptualization, M.H. and A.P.; methodology, L.O., M.H., P.Š., D.V., M.V. (Marta Velíková), M.V. (Michala Vosátková), M.V. (Markéta Vaňková), K.A., H.K., M.K., M.D., R.K.; software, M.H.; validation, M.H. and L.O.; formal analysis, R.K.; investigation, L.O., M.H., D.V.; resources, M.H.; data curation, M.D. and J.B.; writing—original draft preparation, L.O.; writingreview and editing, M.H., P.Š. and R.K.; visualization, L.O. and M.H.; supervision, M.H., P.Š. and A.P.; project administration, M.H. and D.V.; funding acquisition, M.H. and A.P. All authors have read and agreed to the published version of the manuscript.

Funding: This research was funded by the Czech Health Research Council, grant numbers NV1730528A and NU20-01-00308 and by Czech Ministry of Health Institute of Endocrinology "Long-term 
conceptual development of the organization (Institute of Endocrinology) based on already reached results", grant number 00023761.

Institutional Review Board Statement: The study was conducted according to the guidelines of the Declaration of Helsinki, and approved by the Ethics Committee of the Institute of Endocrinology (16 May 2016).

Informed Consent Statement: Informed consent was obtained from all subjects involved in the study. Data Availability Statement: Not applicable.

Acknowledgments: The authors appreciate the excellent technical assistance of Ivona Králová and the outstanding administrative support of Helena Včeláková.

Conflicts of Interest: The authors declare no conflict of interest. The funders had no role in the design of the study; in the collection, analyses, or interpretation of data; in the writing of the manuscript, or in the decision to publish the results.

\section{References}

1. Plows, J.F.; Stanley, J.L.; Baker, P.N.; Reynolds, C.M.; Vickers, M.H. The pathophysiology of gestational diabetes mellitus. Int. J. Mol. Sci. 2018, 19, 3342. [CrossRef]

2. Simjak, P.; Cinkajzlova, A.; Anderlova, K.; Parizek, A.; Mraz, M.; Krsek, M.; Haluzik, M. The role of obesity and adipose tissue dysfunction in gestational diabetes mellitus. J. Endocrinol. 2018, 238, R63-R77. [CrossRef] [PubMed]

3. Cinkajzlova, A.; Anderlova, K.; Simjak, P.; Lacinova, Z.; Klouckova, J.; Kratochvilova, H.; Krejci, H.; Parizek, A.; Mraz, M.; Krsek, M.; et al. Subclinical Inflammation and adipose tissue lymphocytes in pregnant females with gestational diabetes mellitus. J. Clin. Endocrinol. Metab. 2020, 105, e3892-e3902. [CrossRef]

4. Moyce, B.L.; Dolinsky, V.W. Maternal $\beta$-cell adaptations in pregnancy and placental signalling: Implications for gestational diabetes. Int. J. Mol. Sci. 2018, 19, 3467. [CrossRef]

5. Naylor, J.; Li, J.; Milligan, C.J.; Zeng, F.; Sukumar, P.; Hou, B.; Sedo, A.; Yuldasheva, N.; Majeed, Y.; Beri, D.; et al. Pregnenolone sulphate- and cholesterol-regulated TRPM3 channels coupled to vascular smooth muscle secretion and contraction. Circ. Res. 2010, 106, 1507-1515. [CrossRef]

6. Majeed, Y.; Agarwal, A.K.; Naylor, J.; Seymour, V.A.; Jiang, S.; Muraki, K.; Fishwick, C.W.; Beech, D.J. Cis-isomerism and other chemical requirements of steroidal agonists and partial agonists acting at TRPM3 channels. Br. J. Pharmacol. 2010, 161, 430-441. [CrossRef] [PubMed]

7. Lesch, A.; Rubil, S.; Thiel, G. Activation and inhibition of transient receptor potential TRPM3-induced gene transcription. Br. J. Pharmacol. 2014, 171, 2645-2658. [CrossRef]

8. Lambert, S.; Drews, A.; Rizun, O.; Wagner, T.F.; Lis, A.; Mannebach, S.; Plant, S.; Portz, M.; Meissner, M.; Philipp, S.E.; et al. Transient receptor potential melastatin 1 (TRPM1) is an ion-conducting plasma membrane channel inhibited by zinc ions. J. Biol. Chem. 2011, 286, 12221-12233. [CrossRef] [PubMed]

9. Drews, A.; Mohr, F.; Rizun, O.; Wagner, T.F.; Dembla, S.; Rudolph, S.; Lambert, S.; Konrad, M.; Philipp, S.E.; Behrendt, M.; et al. Structural requirements of steroidal agonists of transient receptor potential melastatin 3 (TRPM3) cation channels. Br. J. Pharmacol. 2014, 171, 1019-1032. [CrossRef]

10. Kudo, K.; Tachikawa, E.; Kashimoto, T. Inhibition by pregnenolone sulfate of nicotinic acetylcholine response in adrenal chromaffin cells. Eur. J. Pharmacol. 2002, 456, 19-27. [CrossRef]

11. Paradiso, K.; Sabey, K.; Evers, A.S.; Zorumski, C.F.; Covey, D.F.; Steinbach, J.H. Steroid inhibition of rat neuronal nicotinic $\alpha 4 \beta 2$ receptors expressed in HEK 293 cells. Mol. Pharmacol. 2000, 58, 341-351. [CrossRef]

12. Morimoto, S.; Jimenez-Trejo, F.; Cerbon, M. Sex steroids effects in normal endocrine pancreatic function and diabetes. Curr. Top. Med. Chem. 2011, 11, 1728-1735. [PubMed]

13. Picard, F.; Wanatabe, M.; Schoonjans, K.; Lydon, J.; O'Malley, B.W.; Auwerx, J. Progesterone receptor knockout mice have an improved glucose homeostasis secondary to $\beta$-cell proliferation. Proc. Natl. Acad. Sci. USA 2002, 99, 15644-15648. [CrossRef]

14. Robles-Diaz, G.; Duarte-Rojo, A. Pancreas: A sex steroid-dependent tissue. Isr. Med. Assoc. J. 2001, 3, 364-368.

15. Majeed, Y.; Tumova, S.; Green, B.L.; Seymour, V.A.; Woods, D.M.; Agarwal, A.K.; Naylor, J.; Jiang, S.; Picton, H.M.; Porter, K.E.; et al. Pregnenolone sulphate-independent inhibition of TRPM3 channels by progesterone. Cell Calcium 2012, 51, 1-11. [CrossRef] [PubMed]

16. De Roo, M.; Boue-Grabot, E.; Schlichter, R. Selective potentiation of homomeric P2X2 ionotropic ATP receptors by a fast non-genomic action of progesterone. Neuropharmacology 2010, 58, 569-577. [CrossRef]

17. Burnstock, G. Purinergic signalling in endocrine organs. Purinergic Signal. 2014, 10, 189-231. [CrossRef] [PubMed]

18. Yaghoubi, N.; Malayev, A.; Russek, S.J.; Gibbs, T.T.; Farb, D.H. Neurosteroid modulation of recombinant ionotropic glutamate receptors. Brain Res. 1998, 803, 153-160. [CrossRef]

19. Yu, R.; Xu, X.H.; Sheng, M.P. Differential effects of allopregnanolone and GABA on kainate-induced lactate dehydrogenase release in cultured rat cerebral cortical cells. Acta Pharmacol. Sin. 2002, 23, 680-684. 
20. Gu, Q.; Moss, R.L. $17 \beta$-Estradiol potentiates kainate-induced currents via activation of the cAMP cascade. J. Neurosci. 1996, 16, 3620-3629. [CrossRef]

21. Jin, Y.; Korol, S.V.; Jin, Z.; Barg, S.; Birnir, B. In intact islets interstitial GABA activates GABA(A) receptors that generate tonic currents in $\alpha$-cells. PLoS ONE 2013, 8, e67228. [CrossRef]

22. Dong, H.; Kumar, M.; Zhang, Y.; Gyulkhandanyan, A.; Xiang, Y.Y.; Ye, B.; Perrella, J.; Hyder, A.; Zhang, N.; Wheeler, M.; et al. $\gamma$-Aminobutyric acid up- and downregulates insulin secretion from $\beta$ cells in concert with changes in glucose concentration. Diabetologia 2006, 49, 697-705. [CrossRef]

23. Park-Chung, M.; Malayev, A.; Purdy, R.H.; Gibbs, T.T.; Farb, D.H. Sulfated and unsulfated steroids modulate $\gamma$-aminobutyric acidA receptor function through distinct sites. Brain Res. 1999, 830, 72-87. [CrossRef]

24. Fodor, L.; Biro, T.; Maksay, G. Nanomolar allopregnanolone potentiates rat cerebellar GABAA receptors. Neurosci. Lett. 2005, 383, 127-130. [CrossRef]

25. Gartside, S.E.; Griffith, N.C.; Kaura, V.; Ingram, C.D. The neurosteroid dehydroepiandrosterone (DHEA) and its metabolites alter 5-HT neuronal activity via modulation of GABAA receptors. J. Psychopharmacol. 2010, 24, 1717-1724. [CrossRef] [PubMed]

26. Hill, M.; Parizek, A.; Cibula, D.; Kancheva, R.; Jirasek, J.E.; Jirkovska, M.; Velikova, M.; Kubatova, J.; Klimkova, M.; Paskova, A.; et al. Steroid metabolome in fetal and maternal body fluids in human late pregnancy. J. Steroid Biochem. Mol. Biol. 2010, 122, 114-132. [CrossRef]

27. Mauvais-Jarvis, F. Role of sex steroids in $\beta$ cell function, growth, and survival. Trends Endocrinol. Metab. 2016, 27, 844-855. [CrossRef]

28. Sutter-Dub, M.T. Rapid non-genomic and genomic responses to progestogens, estrogens, and glucocorticoids in the endocrine pancreatic B cell, the adipocyte and other cell types. Steroids 2002, 67, 77-93. [CrossRef]

29. Ropero, A.B.; Alonso-Magdalena, P.; Quesada, I.; Nadal, A. The role of estrogen receptors in the control of energy and glucose homeostasis. Steroids 2008, 73, 874-879. [CrossRef]

30. Moller, C.; Netzer, R. Effects of estradiol on cardiac ion channel currents. Eur. J. Pharmacol. 2006, 532, 44-49. [CrossRef] [PubMed]

31. Cabrera, O.; Jacques-Silva, M.C.; Speier, S.; Yang, S.N.; Kohler, M.; Fachado, A.; Vieira, E.; Zierath, J.R.; Kibbey, R.; Berman, D.M.; et al. Glutamate is a positive autocrine signal for glucagon release. Cell Metab. 2008, 7, 545-554. [CrossRef] [PubMed]

32. Nadal, A.; Ropero, A.B.; Fuentes, E.; Soria, B.; Ripoll, C. Estrogen and xenoestrogen actions on endocrine pancreas: From ion channel modulation to activation of nuclear function. Steroids 2004, 69, 531-536. [CrossRef] [PubMed]

33. Pluchino, N.; Luisi, M.; Lenzi, E.; Centofanti, M.; Begliuomini, S.; Freschi, L.; Ninni, F.; Genazzani, A.R. Progesterone and progestins: Effects on brain, allopregnanolone and $\beta$-endorphin. J. Steroid Biochem. Mol. Biol. 2006, 102, 205-213. [CrossRef]

34. Hill, M.; Paskova, A.; Kanceva, R.; Velikova, M.; Kubatova, J.; Kancheva, L.; Adamcova, K.; Mikesova, M.; Zizka, Z.; Koucky, M.; et al. Steroid profiling in pregnancy: A focus on the human fetus. J. Steroid Biochem. Mol. Biol. 2014, 139, 201-222. [CrossRef] [PubMed]

35. Feng, Y.; Feng, Q.; Qu, H.; Song, X.; Hu, J.; Xu, X.; Zhang, L.; Yin, S. Stress adaptation is associated with insulin resistance in women with gestational diabetes mellitus. Nutr. Diabetes 2020, 10, 4. [CrossRef]

36. Hennebert, O.; Chalbot, S.; Alran, S.; Morfin, R. Dehydroepiandrosterone $7 \alpha$-hydroxylation in human tissues: Possible interference with type 1 11ß-hydroxysteroid dehydrogenase-mediated processes. J. Steroid Biochem. Mol. Biol. 2007, 104, 326-333. [CrossRef] [PubMed]

37. Auci, D.L.; Reading, C.L.; Frincke, J.M. 7-Hydroxy androstene steroids and a novel synthetic analogue with reduced side effects as a potential agent to treat autoimmune diseases. Autoimmun. Rev. 2009, 8, 369-372. [CrossRef]

38. Li, G.; Gao, W.; Xu, Y.; Xie, M.; Tang, S.; Yin, P.; Guo, S.; Chu, S.; Sultana, S.; Cui, S. Serum metabonomics study of pregnant women with gestational diabetes mellitus based on LC-MS. Saudi J. Biol. Sci. 2019, 26, 2057-2063. [CrossRef]

39. Hill, M.; Hana, V., Jr.; Velikova, M.; Parizek, A.; Kolatorova, L.; Vitku, J.; Skodova, T.; Simkova, M.; Simjak, P.; Kancheva, R.; et al. A method for determination of one hundred endogenous steroids in human serum by gas chromatography-tandem mass spectrometry. Physiol. Res. 2019, 68, 179-207. [CrossRef]

40. Brochu, M.; Belanger, A. Comparative study of plasma steroid and steroid glucuronide levels in normal men and in men with benign prostatic hyperplasia. Prostate 1987, 11, 33-40. [CrossRef]

41. Sanchez-Guijo, A.; Oji, V.; Hartmann, M.F.; Traupe, H.; Wudy, S.A. Simultaneous quantification of cholesterol sulfate, androgen sulfates, and progestagen sulfates in human serum by LC-MS/MS. J. Lipid Res. 2015, 56, 1843-1851. [CrossRef]

42. Labrie, F.; Belanger, A.; Cusan, L.; Gomez, J.L.; Candas, B. Marked decline in serum concentrations of adrenal C19 sex steroid precursors and conjugated androgen metabolites during aging. J. Clin. Endocrinol. Metab. 1997, 82, 2396-2402. [CrossRef]

43. Brochu, M.; Belanger, A.; Dupont, A.; Cusan, L.; Labrie, F. Effects of flutamide and aminoglutethimide on plasma $5 \alpha$-reduced steroid glucuronide concentrations in castrated patients with cancer of the prostate. J. Steroid Biochem. 1987, 28, 619-622. [CrossRef]

44. Tokushige, K.; Hashimoto, E.; Kodama, K.; Tobari, M.; Matsushita, N.; Kogiso, T.; Taniai, M.; Torii, N.; Shiratori, K.; Nishizaki, Y.; et al. Serum metabolomic profile and potential biomarkers for severity of fibrosis in nonalcoholic fatty liver disease. J. Gastroenterol. 2013, 48, 1392-1400. [CrossRef]

45. Meng, L.J.; Reyes, H.; Axelson, M.; Palma, J.; Hernandez, I.; Ribalta, J.; Sjovall, J. Progesterone metabolites and bile acids in serum of patients with intrahepatic cholestasis of pregnancy: Effect of ursodeoxycholic acid therapy. Hepatology 1997, 26, 1573-1579. [CrossRef] [PubMed] 
46. Abu-Hayyeh, S.; Papacleovoulou, G.; Lovgren-Sandblom, A.; Tahir, M.; Oduwole, O.; Jamaludin, N.A.; Ravat, S.; Nikolova, V.; Chambers, J.; Selden, C.; et al. Intrahepatic cholestasis of pregnancy levels of sulfated progesterone metabolites inhibit farnesoid $X$ receptor resulting in a cholestatic phenotype. Hepatology 2013, 57, 716-726. [CrossRef] [PubMed]

47. Meloun, M.; Hill, M.; Militky, J.; Kupka, K. Transformation in the PC-aided biochemical data analysis. Clin. Chem. Lab. Med. 2000, 38, 553-559. [CrossRef]

48. Meloun, M.; Militky, J.; Hill, M.; Brereton, R.G. Crucial problems in regression modelling and their solutions. Analyst 2002, 127, 433-450. [CrossRef]

49. Miller, W.L.; Auchus, R.J. The molecular biology, biochemistry, and physiology of human steroidogenesis and its disorders. Endocr. Rev. 2011, 32, 81-151. [CrossRef] [PubMed]

50. Luu-The, V. Assessment of steroidogenesis and steroidogenic enzyme functions. J. Steroid Biochem. Mol. Biol. 2013, 137, 176-182. [CrossRef] [PubMed]

51. Karahoda, R.; Kallol, S.; Groessl, M.; Ontsouka, E.; Anderle, P.; Fluck, C.; Staud, F.; Albrecht, C. Revisiting steroidogenic pathways in the human placenta and primary human trophoblast cells. Int. J. Mol. Sci. 2021, 22, 1704. [CrossRef] [PubMed]

52. Pasqualini, J.R.; Chetrite, G.S. The formation and transformation of hormones in maternal, placental and fetal compartments: Biological implications. Horm. Mol. Biol. Clin. Investig. 2016, 27, 11-28. [CrossRef] [PubMed]

53. Chatuphonprasert, W.; Jarukamjorn, K.; Ellinger, I. Physiology and pathophysiology of steroid biosynthesis, transport and metabolism in the human placenta. Front. Pharmacol. 2018, 9, 1027. [CrossRef]

54. Gupta, M.K.; Guryev, O.L.; Auchus, R.J. $5 \alpha$-reduced C21 steroids are substrates for human cytochrome P450c17. Arch. Biochem. Biophys. 2003, 418, 151-160. [CrossRef]

55. Lambert, J.J.; Belelli, D.; Peden, D.R.; Vardy, A.W.; Peters, J.A. Neurosteroid modulation of GABAA receptors. Prog. Neurobiol. 2003, 71, 67-80. [CrossRef] [PubMed]

56. Weir, C.J.; Ling, A.T.; Belelli, D.; Wildsmith, J.A.; Peters, J.A.; Lambert, J.J. The interaction of anaesthetic steroids with recombinant glycine and GABAA receptors. Br. J. Anaesth. 2004, 92, 704-711. [CrossRef]

57. Irwin, R.P.; Lin, S.Z.; Rogawski, M.A.; Purdy, R.H.; Paul, S.M. Steroid potentiation and inhibition of N-methyl-D-aspartate receptor-mediated intracellular $\mathrm{Ca}^{+}$responses: Structure-activity studies. J. Pharmacol. Exp. Ther. 1994, 271, 677-682.

58. Dayanithi, G.; Tapia-Arancibia, L. Rise in intracellular calcium via a nongenomic effect of allopregnanolone in fetal rat hypothalamic neurons. J. Neurosci. 1996, 16, 130-136. [CrossRef] [PubMed]

59. Ranna, M.; Sinkkonen, S.T.; Moykkynen, T.; Uusi-Oukari, M.; Korpi, E.R. Impact of epsilon and theta subunits on pharmacological properties of $\alpha 3 \beta 1$ GABAA receptors expressed in Xenopus oocytes. BMC Pharmacol. 2006, 6, 1. [CrossRef]

60. Malayev, A.; Gibbs, T.T.; Farb, D.H. Inhibition of the NMDA response by pregnenolone sulphate reveals subtype selective modulation of NMDA receptors by sulphated steroids. Br. J. Pharmacol. 2002, 135, 901-909. [CrossRef]

61. Vyklicky, V.; Krausova, B.; Cerny, J.; Balik, A.; Zapotocky, M.; Novotny, M.; Lichnerova, K.; Smejkalova, T.; Kaniakova, M.; Korinek, M.; et al. Block of NMDA receptor channels by endogenous neurosteroids: Implications for the agonist induced conformational states of the channel vestibule. Sci. Rep. 2015, 5, 10935. [CrossRef]

62. Majeed, Y.; Amer, M.S.; Agarwal, A.K.; McKeown, L.; Porter, K.E.; O’Regan, D.J.; Naylor, J.; Fishwick, C.W.; Muraki, K.; Beech, D.J. Stereo-selective inhibition of transient receptor potential TRPC5 cation channels by neuroactive steroids. Br. J. Pharmacol. 2011, 162, 1509-1520. [CrossRef]

63. Riccio, A.; Li, Y.; Moon, J.; Kim, K.S.; Smith, K.S.; Rudolph, U.; Gapon, S.; Yao, G.L.; Tsvetkov, E.; Rodig, S.J.; et al. Essential role for TRPC5 in amygdala function and fear-related behavior. Cell 2009, 137, 761-772. [CrossRef]

64. Lundgren, P.; Stromberg, J.; Backstrom, T.; Wang, M. Allopregnanolone-stimulated GABA-mediated chloride ion flux is inhibited by $3 \beta$-hydroxy-5 $\alpha$-pregnan-20-one (isoallopregnanolone). Brain Res. 2003, 982, 45-53. [CrossRef]

65. Wang, M.; He, Y.; Eisenman, L.N.; Fields, C.; Zeng, C.M.; Mathews, J.; Benz, A.; Fu, T.; Zorumski, E.; Steinbach, J.H.; et al. 3ß-hydroxypregnane steroids are pregnenolone sulfate-like GABA(A) receptor antagonists. J. Neurosci. 2002, 22, 3366-3375. [CrossRef]

66. Reddy, D.S. Anticonvulsant activity of the testosterone-derived neurosteroid 3 $\alpha$-androstanediol. Neuroreport 2004, 15, 515-518. [CrossRef] [PubMed]

67. Mtchedlishvili, Z.; Sun, C.S.; Harrison, M.B.; Kapur, J. Increased neurosteroid sensitivity of hippocampal GABAA receptors during postnatal development. Neuroscience 2003, 118, 655-666. [CrossRef]

68. Horak, M.; Vlcek, K.; Chodounska, H.; Vyklicky, L., Jr. Subtype-dependence of N-methyl-D-aspartate receptor modulation by pregnenolone sulfate. Neuroscience 2006, 137, 93-102. [CrossRef]

69. Traish, A.M.; Guay, A.T.; Zitzmann, M. 5 $\alpha$-Reductase inhibitors alter steroid metabolism and may contribute to insulin resistance, diabetes, metabolic syndrome and vascular disease: A medical hypothesis. Horm. Mol. Biol. Clin. Investig. 2014, 20, 73-80. [CrossRef]

70. Hirst, J.J.; Kelleher, M.A.; Walker, D.W.; Palliser, H.K. Neuroactive steroids in pregnancy: Key regulatory and protective roles in the foetal brain. J. Steroid Biochem. Mol. Biol. 2014, 139, 144-153. [CrossRef] [PubMed]

71. Milewich, L.; Gant, N.F.; Schwarz, B.E.; Chen, G.T.; MacDonald, P.C. $5 \alpha$-Reductase activity in human placenta. Am. J. Obstet. Gynecol. 1979, 133, 611-617. [CrossRef]

72. BioGPS; 2011/11/13; Affymetrix: Santa Clara, CA, USA, 2016. 
73. Manjunath-Gowda, S.; Charles, C.; Muneyyirci-Delale, O.; Nacharaju, V. Cortisol metabolism in normal pregnancy and pregnancy associated with gestational diabetes. Fertil. Steril. 2013, 100, S333. [CrossRef]

74. Upreti, R.; Hughes, K.A.; Livingstone, D.E.; Gray, C.D.; Minns, F.C.; Macfarlane, D.P.; Marshall, I.; Stewart, L.H.; Walker, B.R.; Andrew, R. 5 $\alpha$-Reductase type 1 modulates insulin sensitivity in men. J. Clin. Endocrinol. Metab. 2014, 99, E1397-E1406. [CrossRef] [PubMed]

75. Nasiri, M.; Nikolaou, N.; Parajes, S.; Krone, N.P.; Valsamakis, G.; Mastorakos, G.; Hughes, B.; Taylor, A.; Bujalska, I.J.; Gathercole, L.L.; et al. $5 \alpha$-Reductase type 2 regulates glucocorticoid action and metabolic phenotype in human hepatocytes. Endocrinology 2015, 156, 2863-2871. [CrossRef] [PubMed]

76. Conrad, D.; Wang, A.; Pieters, R.; Nicoletti, F.; Mangano, K.; van Heeckeren, A.M.; White, S.K.; Frincke, J.M.; Reading, C.L.; Stickney, D.; et al. HE3286, an oral synthetic steroid, treats lung inflammation in mice without immune suppression. J. Inflamm. 2010, 7, 52. [CrossRef]

77. Li, H.; Lampe, J.N. Neonatal cytochrome P450 CYP3A7: A comprehensive review of its role in development, disease, and xenobiotic metabolism. Arch. Biochem. Biophys. 2019, 673, 108078. [CrossRef]

78. Chiodini, I.; Adda, G.; Scillitani, A.; Coletti, F.; Morelli, V.; Di Lembo, S.; Epaminonda, P.; Masserini, B.; Beck-Peccoz, P.; Orsi, E.; et al. Cortisol secretion in patients with type 2 diabetes: Relationship with chronic complications. Diabetes Care 2007, $30,83-88$. [CrossRef] 